\title{
A Buried Past: The Tomb Inscription (Muzhiming) and Official Biographies of Wang Chuzhi (863-923)
}

\author{
Angela Schottenhammer*
}

\begin{abstract}
The present article investigates the tomb inscription of Wang Chuzhi (863-923), a military governor whose career spanned the end of the Tang and the beginning of the Five Dynasties. By comparing the inscription with representations of the deceased in official sources, the article reveals that the tomb inscription presents a critical attitude toward the moral standards of conventional historiography, and demonstrates a shifting moral geography in the works of Song historians. This new standard increasingly excluded nomadic peoples from the newly imagined political body, and excluded with them the pragmatic diplomacy that had characterized the politics of the Five Dynasties.
\end{abstract}

Cet article analyse l'inscription funéraire de Wang Chuzhi (863-923). Ce gouverneur militaire vécut à la fin des Tang et au début de la période des Cinq Dynasties. La comparaison de l'inscription à diverses représentations du défunt contenues dans les sources officielles montre la manière dont l'auteur de l'inscription critique les standards moraux de l'historiographie officielle. Elle montre aussi le cadre géographique mouvant dans lequel s'appliquait la morale Song: les populations nomades étaient de plus en plus exclues du corps politique tel qu'il était alors imaginé; la diplomatie pragmatique qui avait dominé la période des Cinq Dynasties était abandonnée.

\section{Keywords}

tomb inscriptions, historiography, dynastic histories, Five Dynasties, Wang Chuzhi

\section{Introduction}

Wang Chuzhi 王處直 (863-923) was a high-ranking Military Commissioner who lived during the closing decades of the Tang (618-907) and the early years of the Five Dynasties (907-960), a time characterized by unceas-

*) Angela Schottenhammer, Sinology, Japanese Studies, Munich University and Marburg University, Germany, angela.schottenhammer@ostasien.fak12.uni-muenchen.de. 
ing bloodshed and war between competing military governors. His tomb is representative of a lavish tenth-century burial. ${ }^{1}$ Although it was robbed at least twice, its internal architecture, in particular its sculpted murals, attests to the relatively high social status of the deceased and to the importance his descendents placed on his tomb. The depiction of an orchestra of female musicians, in the midst of a performance, is particularly arresting. ${ }^{2}$ Wang Chuzhi's tomb also contained a tomb inscription (muzhiming 墓誌銘) that provides us with additional information about the deceased (see figures 1 and 2). ${ }^{3}$

Funerary inscriptions are authentic archaeological and historical materials of great value, which, as the example of Wang Chuzhi will show, can contain interesting and important additional information on historical events and personalities. Such inscriptions were composed as personal biographies of the deceased (muzhi 墓誌), ending as a rule with a rhymed eulogy (ming 銘). ${ }^{4}$ Naturally, these inscriptions vary in length and detail of historical information. Using tomb inscriptions as a source for historical analysis, however, the historian has to distinguish between archaeological inscriptions - carved in stone or stone-like material and placed into the tomb, and thus literally buried with the deceased - and the literary versions of the inscriptions that were transmitted on paper. ${ }^{5}$ The inscription

1) Hebeisheng wenwu yanjiusuo 河北省文物研究所 and Baodingshi wenwu guanlichu 保定市文物管理處, Wudai Wang Chuzhi mu 五代王處直墓 (Beijing: Wenwu chubanshe, 1998).

2) See Wudai Wang Chuzhi mu for colored illustrations. For a brief analysis of the musical instruments depicted, see Angela Schottenhammer, “Das Grab des Wang Chuzhi 王處直 (863-923)." In Auf den Spuren des Jenseits: Chinesische Grabkultur in den Facetten von Wirklichkeit, Geschichte und Totenkult, ed. Angela Schottenhammer (Frankfurt: Peter Lang, 2003): 85-9.

3) See Wudai Wang Chuzhi mu: 64-6, black-and-white plates 10-1.

4) For the history of rhymed eulogies as a part of tomb inscriptions, see Angela Schottenhammer, "Einige Überlegungen zur Entstehung von Grabinschriften." In Auf den Spuren des Jenseits, ed. Schottenhammer: 21-59.

5) As a rule, tomb inscriptions were placed at the head or the foot of the coffin, often set in a pit especially designed for them. Cf. Angela Schottenhammer, "Characteristics of Song Epitaphs." In Burial in Song China, ed. Dieter Kuhn (Heidelberg: edition forum, 1995): 255. Since tomb inscriptions were often composed by famous scholar-officials and literati, many such texts are preserved in collected works (wenji 文集) as well as in anthologies, writing manuals, and other collections. The fame of the authors ensured that many tomb inscriptions also survived in the form of rubbings from the original stone. A comparison between the archaeological and transmitted versions of tomb inscriptions, along with other accounts of the deceased, can yield interesting information about the intentions of the 
analyzed below is the original stone inscription that was excavated from the tomb of Wang Chuzhi. Unfortunately, we do not possess a transmitted paper version of this tomb inscription that might provide us with additional clues about the politics of its composition.

It was conventional among the social elite of the time that a son of the deceased solicited a tomb inscription for his father. As a rule, the inscription was composed by a man who did not belong to the immediate family circle, preferably (if the family of the deceased could afford it) by a renowned literatus or literatus-official. In the case of Wang Chuzhi, it was most likely his son, Wang Du 王都 (d. 929), who requested the tomb inscription. Its author was a certain He Shaowei 和少微 (alias He Zhaoxun 和昭訓) who served as a clerk (shuli 書吏) under Wang Du in Yiwu 義武 commandery. Official accounts concerning the person of Wang Du differ from statements in the tomb inscription almost from the very first line. According to the inscription, Wang Chuzhi married as his third wife a Miss Bu $卜$, Lady of Chu, and Wang Du was her son (ji Chuguo furen zhi $z i$ ye 即楚國夫人之子也). ${ }^{6}$ In all other official sources, however, Wang Du is identified as the adoptive son of Wang Chuzhi, given to him by a mysterious man named Li Yingzhi 李應之. The exact historical circumstances remain unclear. Most probably, however, this Miss Bu was chosen as a kind of adoptive mother in order to safeguard the legitimacy of Wang Du as the legal successor to Wang Chuzhi and to pre-empt the impression that Wang Du had simply "displaced" ( $f e i$ 廢) his father in office, as the Old History of the Tang (Jiu Tang shu 舊唐書) and the Old History of the Five Dynasties (Jiu Wudai shi 舊五代史) imply. ${ }^{\top}$

The position and status of Wang Du in relation to Wang Chuzhi is thus ambiguous. Sources starting with the New History of the Five Dynasties (Xin Wudai shi 新五代史) tell us that Chuzhi loved Du. But, according to Ouyang Xiu, when Du became worried about his political career and family status he not only succeeded Chuzhi in his official military career, but also did not shrink from kidnapping and perhaps even killing his father. Neither tenth-century official sources nor the funerary inscription, how-

authors, who sometimes deleted, added, or changed historical or biographical information, to suit their audience or their historical circumstances. Cf. also Sue Takashi's contribution to this issue.

6) Wudai Wang Chuzhi mu: 65.

7) See Liu Xu 劉煦 (887-946), Jiu Tang shu 舊唐書 (945; reprint Beijing: Zhonghua shuju, 1997): 182.4701; Xue Juzheng 薛居正 (912-981), Jiu Wudai shi 舊五代史 (974; reprint Beijing: Zhonghua shuju, 1997): 54.731. 
ever, mention these events. According to these latter texts, Wang Chuzhi retired to his Western Residence (Chuzhi gui xidi 處直歸西第) and died not long afterward, presumably of natural causes. ${ }^{8}$

A comparative analysis of Wang Chuzhi's tomb inscription, his official biographies, and entries on his life and career in two other famous Songdynasty historical works provides us with a lively picture of the shifting assessment, from the early Five Dynasties through the Song period, of an intriguing military personality. The analysis reveals in a general fashion what kind of behavior was considered evil, and which kinds of behavior were criticized as disruptions of the regular order of the family, the state, and the natural world. More specifically, the materials provide us with a vivid example of the shifting moral geography of the Song Empire, which increasingly excluded nomadic peoples from its newly imagined political body, and excluded with them the pragmatic diplomacy that had characterized the politics of the Five Dynasties.

\section{Wang Chuzhi's Tomb Inscription}

Wang Chuzhi's tomb inscription begins with the usual list of titles and positions held by the deceased, followed by the titles and the name of the author of the inscription, and an opening paragraph full of allusions to events during the Han period and to Wang Chuzhi's alleged ancestry (see below). This is followed by information about Wang Chuzhi's home and family, with some detail about the lives of his grandfather, father, and elder half-brother. The latter, the elder half-brother Wang Chucun 王處存 (d. 895), is singled out for special praise because of his glorious military successes, which enabled the people of the era once again to live in peace. Subsequently, He Zhaoxun sets forth the political circumstances of the time, elaborating in particular on the power struggles between military governors, and he gives special attention to the initial confrontation and later alliance of Wang Chuzhi with Zhu Wen 朱溫 (852-911), the founder of the Liang 梁 dynasty (907-923). Zhu Wen was one of the most powerful military governors of the time, with Li Keyong 李克用 (856-912) and Li Maozhen 李茂貞 (856-924) as his greatest enemies. ${ }^{9}$ He Zhaoxun

\footnotetext{
8) See Wudai Wang Chuzhi mu: 65.

9) For a detailed analysis of the developments in north China during this period, see Wang Gungwu, Divided China: Preparing for Reunification, 883-947 (Singapore: World Scientific
} 
describes in detail a historical battle that took place in 900 between the army led by the deceased and the troops of Zhu Wen: ${ }^{10}$

They fought from early morning until night, but the battle remained undecided. Then, my lord risked that the dust would turn red [i.e., he staked everything on one chance] and rushed forward with naked blades. The battle was dreadful, as the sky turned dark and the sun set; they fought bitterly, till the swords ran out and the bows broke.... Zhu Wen was frightened to death that my lord would use the secret tactic of the ox-drawn fire-chariots of the state of Qi, the awful roar of the bound tigers of the state of Lü. ${ }^{11}$

In the assessment of Wang Chuzhi's character that follows upon the account of his military career, He Zhaoxun emphasizes Chuzhi's erudition and his moral uprightness, by listing his scholarly achievements and by comparing him to learned, unbending military paragons of the past: ${ }^{12}$

In wielding knife and brush in the resplendent lotus-red field office, he equalled Ruan Yu 阮㻦 [c. 165-212] and Chen Lin 陳琳 [d. 217]; in carrying quiver and bow sack in the hidden willow-green battle camp, he matched Lian Po 廉頗 and Li Mu 李牧 [d. $228 \mathrm{BCE}] .^{13}$

Ruan Yu and Chen Lin were both famous literati, engaged in politics and military affairs during the late Han dynasty. Both were members of the Seven Poets of the Jian'an era (Jian'an qizi 建安七子). Ruan Yu was originally a student of Cai Yong 蔡邑 (133-192) and served later, as did Chen Lin, as a general for Cao Cao 曹操 (155-220). Lian Po and Li Mu were both generals of the state of Zhao 趙 during the Warring States period

Publishing, 2007 [1967]); Zhu Yulong 朱玉龍, ed., Wudai shiguo fangzhen nianbiao 五代十國方鎮年表 (Beijing: Zhonghua shuju, 1997).

10) For a more detailed analysis of Wang Chuzhi's tomb and tomb inscription, see Schottenhammer, "Das Grab": 61-118.

11) Cf. Schottenhammer, "Das Grab": 93-4. Ox-drawn fire-chariots were first used in battle by the armies of the state of Qi, during their invasion of Yan. Not only were sharp blades attached to the horns of the oxen, but mats and ropes were tied to their tails and set alight, so that the terrified animals stampeded toward the enemy.

12) He wrote commentaries on the Spring and Autumn Annals (Chunqiu), enriched Confucianism, Daoism, and Buddhism with his ideas, and penetrated deeply into the nine categories of philosophy. See Wudai Wang Chuzhi mu: 65. It should be added that Wang Du, too, is described as a person who was fond of books. See Xue Juzheng, Jiu Wudai shi: 54.733.

13) Wudai Wang Chuzhi mu: 65. 
(475/463-221 BCE), and both represent martial strength. ${ }^{14}$ Lian Po defeated two Qin armies in 269 BCE. Li Mu was very successful in his battles against northern peoples, in particular the Xiongnu 匈奴. However, his strategy against the raids of the Xiongnu was peculiar. He bided his time for a counter-attack so patiently that the Xiongnu, his own men, and his king eventually believed him to be a coward. "The King of Zhao angrily summoned him and sent another man to replace him as general." ${ }^{15}$ After the Xiongnu had invaded Zhao for over a year, the king asked $\mathrm{Li} \mathrm{Mu}$ to return. Li Mu was once again successful with his tactics, and "for more than a dozen years... the Xiongnu did not dare to approach the walled border of the cities of Zhao." ${ }^{16}$ All four men summoned in this dense couplet, in other words, were both successful generals and erudite scholars.

Elsewhere in the inscription, He Zhaoxun compares Wang Chuzhi to Fu Yue 傅說, Yuan An 袁安 (d. 92), Mengming 孟明, and Guo Wei 郭隗. We are told that "to save the times from disaster, he poured forth the heavy rains of Fu Yue; as he worried about the country, he shed the tears of Yuan An." ${ }^{17} \mathrm{Fu}$ Yue was a convict working in the cliffs of Fu when he was employed as prime minister by King Wuding 武丁 (r. 1250-1192 BCE) of the Yin dynasty, thus rising from a mean position to a most respectable rank. ${ }^{18}$ Yuan An was a prominent scholar and statesman during the Han dynasty, under the Emperors Zhangdi 章帝 (r. 76-88) and Hedi 和帝 (r. 89-105). ${ }^{19}$ He played an active role in the discussions at court regarding the policy of the Han Empire toward the Xiongnu. After the death of Emperor Zhangdi, the Han court once again adopted an aggressive policy against the Xiongnu. Yuan An submitted memorials to the court condemning a campaign against the Xiongnu. He argued that since the Northern Xiongnu had not invaded the borderlands, there was no reason to waste resources on a distant expedition. Despite his strong opposition, in which he was supported by other conservative advisors, Lady Dou 䆬

14) See Sima Qian 司馬遷, Shiji 史記 (91 BCE; reprint Beijing: Zhonghua shuju, 1994):

81.2439-52.

15) Sima Qian, Shiji: 81.2449.

16) Sima Qian, Shiji: 81.2450.

17) Wudai Wang Chuzhi mu: 65.

18) See Sima Qian, Shiji: 124.3812, translated below. See also Sima Qian, Shiji: 3.102, 28.1356.

19) Yuan An is mentioned repeatedly in the History of the Later Han. See Fan Ye 范曄, Hou Han shu 後漢書 (fifth century; reprint Beijing: Zhonghua shuju, 1965): 51.754, 67.1265, 75.1517. 
ordered the dispatch of an expeditionary force. In the summer of $89 \mathrm{CE}$, a Han force advanced in three columns with minimal opposition, defeated the Northern Xiongnu leader, the Shanyu 單于, and pursued him westward into the Altai mountain range. A final offensive in 91 destroyed the Northern Xiongnu, creating a political vacuum in its former territories, which the Han Empire would struggle to contain during the next century. The allusion to the tears of Yuan An may therefore be intended to convey that Wang Chuzhi (and Wang Du?) was likewise worried about his country, and that he opposed the aggressive policy of his rivals, such as Zhu Wen or Li Cunxu 李存勗. Like many others, these men claimed a commitment to the restoration of the Tang dynasty.

The comparison to Mengming and Guo Wei is merited, according to He Zhaoxun, by the range and depth of Wang Chuzhi's scholarship. During the reign of Duke Mu 穆公 (659-621 BCE), ruler of the state of Qin, Mengming (the polite name of Baili Shi 百里視) served as a general, subjugating various regions and extending the Qin territory westward. Having been ordered, in 627, to attack the state of Zheng 鄭, he was himself ambushed by Jin 晋 troops and subsequently taken prisoner, but he was released again by the Marquis of Jin. ${ }^{20}$ In the second year of the rule of Wengong 文公 he "led an army against Jin to repay his defeat at Xiao 崤," but Qin once more suffered a severe defeat. The Earl of Qin nonetheless continued to employ Mengming, who paid increasing attention to government and bestowed great largesse on the people. ${ }^{21}$ He eventually took up arms again and defeated the Jin army. ${ }^{22}$ Guo Wei was a great statesman from Yan 燕 during the Warring States period. In 314 BCE, King Xuan 宣王 (r. 319-301) of Qi took advantage of a near civil war in Yan (occasioned by disputes about the line of succession) to conquer the state, win-

20) These events are recorded in Zuozhuan, thirty-third year of Duke Xi. Cf. James Legge, The Ch'un T'sew with the Tso Chuen (Taipei: SMC Publishing, 1994 [1872]): 222-6. Both in the thirty-third year of Duke Xi and in the first year of Duke Wen, the Earl of Qin took full responsibility for the defeat of his generals, citing the inadequacy of his own judgment: "By my opposition to the counsel of Jian Shu I brought disgrace on you, my generals. Mine has been the crime, and that I did not [before] dismiss Mengming [from such a service in the army] was my fault. What fault are you chargeable with? I will not for one error shut out of view your great merits." And: "It was my covetousness which brought the misfortune on [Mengming]. What crime had he?' Accordingly he again employed [Mengming] in the conduct of the government." See Legge, The Ch'un T'́ew: 225, 230.

21) See Legge, The Ch'un Ts'ew: 232-3.

22) See Legge, The Ch'un Ts'ew: 235-6. 
ning a great victory over the Yan troops. The cruelty of the invaders, however, caused a rebellion in Yan, and the Qi troops eventually had to withdraw. King Zhao 昭王 (r. 311-279 BCE) of Yan thereupon planned to revenge the former attack by Qi. Seeking competent, reliable, and morally upright followers to assist him in this purpose, he selected Guo Wei as his ideal candidate. King Zhao even had a great palace erected for him. ${ }^{23}$ The expression Guo Wei gong 郭隗宮 was used in later times to denote a venue for competent, reliable, and upright men.

In a final comparison, He Zhaoxun cites Fan Li 范蟙, a high official and general in the state of Yue 越 during the late Spring and Autumn period. After his troops had been routed by the army of the state of Wu at Kuaijishan 會稽山 (southeast of Hangzhou, Zhejiang province), Fan Li, too, resolved to make good his defeat and eventually succeeded in smashing the Wu army. It is said that he subsequently changed his name and became a wealthy merchant. ${ }^{24}$ Fan $\mathrm{Li}$, in other words, was yet another historical general who suffered a crushing defeat yet eventually was able to compensate for his dishonor, defeating his erstwhile enemy and then retiring to become a wealthy farmer and merchant.

Wang Chuzhi, who lost a decisive battle in 900, of course bears a striking resemblance to these historical generals. Although Wang, unlike Mengming and others, was unable to make amends for the shame of his defeat, he shared with them a life and a career beset by difficult circumstances that nonetheless led to a favorable conclusion. ${ }^{25}$

After the assessment of Wang Chuzhi's character, the tomb inscription describes the hopes for peaceful times entertained by his subjects during a period of war, looking forward to a time when peasants will once again be able to till their fields - an ideal of a peaceful, harmonious co-existence of people, animals, and nature that is also expressed in the decoration of the tomb. When stressing the importance of preserving virtuous actions in durable records, for example, the tomb inscription mentions the carved dragons and sculpted phoenixes of commemorative steles:

23) See Sima Qian, Shiji: 34.1558.

24) Fan Li, originally from Chu 楚, served Goujian 句践, King of Yue, in defeating Wu 吳. Thereupon he left for the state of Qi 齊, where he settled in Tao 陶 and called himself the Honorable Zhu 朱 of Tao. See Sima Qian, Shiji: 41.1740-56.

25) Perhaps Wang Du felt compelled to make amends for Wang Chuzhi's dishonor by taking matters into his own hands, and serving the cause of his state. Military defeat appears to have been deemed universally shameful during this period. 
If not the round and pointed maces preserved [evidence of] good government, how could one ever learn about the men of remote antiquity: ${ }^{26}$ Thereafter: with serpent head [chitou 螭頭] and tortoise foot [guifu 龜跃], one slab supported by a sea turtle [ao 鰲]; over dragon patterns and caltrop shapes, a thousand words produced by phoenixes. ${ }^{27}$

There are pairs of phoenixes painted on the upper register of the chamber in which the coffin and tomb inscription were placed. The inscription, the construction, and the decoration of the tomb together represent the deceased as an individual worthy of being honored.

The account of Wang Chuzhi's life ends with his quiet retirement and death, and a list of his offspring. In the winter of 923, Chuzhi asks his son for permission to resign his official position, citing his advanced age. $\mathrm{He}$ spends his final months at his Western Residence. The inscription also dedicates a few words to Chuzhi's good moral character, before describing the natural and geographic locality of his burial place. The inscription concludes with a rhymed eulogy. It is important to emphasize that the tomb inscription contains passages throughout that are difficult to understand and are often ambiguous. ${ }^{28}$ In sum, however, the author draws a very positive portrait of the deceased, as a loyal, ambitious, and erudite general who had the misfortune of losing a decisive battle under difficult circumstances.

Wang Chuzhi's funerary inscription contributes to our understanding of two aspects of Five Dynasties politics: military strategy and society, and ideology and moral thought. Moral values and virtues abound in the inscription, such as military success (or at least ambitious attempts at military success) in the service of the people and, above all, in the service of the political goals of one's country; the endeavor to ensure the welfare of the people by establishing peace and long-term stability; commemoration of ancestors and their successes, and so forth.

It is not surprising that members of the political and social elites of the time, including the author of this tomb inscription, saw clear parallels

26) “The round and pointed maces" (wanyan 琬琰) appear to have been precious stones that could be used for durable inscriptions - not unlike tomb inscriptions. Cf. James Legge, The Shoo King (Taipei: SMC Publishing, 1994 [1865]): 554: "There were the red knife, the great lessons, the large convex symbol of the gem, and the rounded and pointed maces—all in the side space of the west."

27) Wudai Wang Chuzhi mu: 65.

28) For an attempt at a full translation and analysis of the inscription, see Schottenhammer, "Das Grab": 73-81, 90-101. 
between the circumstances of their world and those of earlier periods. This interest in historical parallels is attested by the reflections on the political circumstances and personalities, most of them generals, of the Zhou, Han, and post-Han periods. The parallels between earlier times and the circumstances of the early tenth century are difficult to deny. The power struggles and intrigues between the political and military elites, attempts to re-establish a unified government, and so forth, provide important similarities between these periods. ${ }^{29}$ Perhaps the author fully intended to keep some passages in the tomb inscription ambiguous in order to make the reader aware of the difficulty of making categorical judgements of political developments and people as either good or bad. I will treat this argument in more detail below. ${ }^{30}$ But at this stage it should already be clear that He Zhaoxun did not simply record the landmark events of Wang Chuzhi's life, but that he repeatedly alluded to historical persons and developments that offer parallels to the experiences of Wang Chuzhi. These references to historical figures and events call the reader's attention to the difficult political and moral circumstances with which the deceased, He Zhaoxun himself, and Wang Du were confronted. The entire inscription therefore reads like an extended argument, proving that the deceased, despite a lost battle and perhaps some other shortcomings, was in fact a good and virtuous person who deserved an honorable place of rest for eternity - a lavishly furnished tomb in harmony with heaven and nature.

The exact cause of Wang Chuzhi's death, meanwhile, remains uncertain. Did he die of natural causes, did he die of grief, or was he murdered? With the exception of the funerary inscription, all historical records say that his son, $\mathrm{Du}$, was at the very least involved in the retirement of his father to the Western Residence, and that Du himself took up his father's former position. To take over one's father's position-much less to displace him, as some sources have it-was not considered an act of filial devotion. Although these matters are of course not explicitly stated in the inscription, the

29) Many military men of the Five Dynasties legitimized their actions by saying that they hoped to restore the Tang dynasty. The political situation bore a certain resemblance to the attempts to restore the Han dynasty after the usurpation by Wang Mang 王莽 (r. 9-23). It was eventually Liu Xiu 劉秀 (6 BCE-57 CE) who defeated Wang Mang and who in 25 CE restored Han rule as Emperor Guangwu 光武 (r. 25-57).

30) Cf. also Schottenhammer, “Das Grab”: 73-81; Xiao Ting 蕭婷 (Angela Schottenhammer), "Wang Chuzhi muzhiming de zaikaocha: guanyu Wudai jiedushi jieji li de yixie daode ji yishi xingtai qushi” 王處直墓誌銘的再考察一關於五代節度使階级裡的一些道 德及意識形態趨势. Zhonghua wenshi luncong 中華文史論叢 4 (2006): 158-77. 
repeated allusions to the politically difficult circumstances of the time, considered in this context, read like a justification, not only of Wang Chuzhi's career, but of the actions of Wang Du, and perhaps of He Zhaoxun himself. $^{31}$

However this may be, the tomb inscription provides us with an alternative version of Chuzhi's life and destiny that differs from all other written accounts we possess. He Zhaoxun's deviation from official historiography, creating a narrative that insists that a man may be a good person despite having lost a battle and in spite of other shortcomings, not only implies that he could write such a narrative without fear of censorship, but also that he was conscious of the difference between officially sponsored morality and the behavior of individuals. Moreover his attempt to explain this difference to his reader implies that the author does not simply dismiss or disdain the established morality of official historiography but that he seeks to show that even actions (or the consequences of actions) that appear to deviate from conventional morality can indeed be in accord with the highest norms and most illustrious precedents of moral behavior.

Since the Five Dynasties, and especially since the Song, funerary inscriptions gradually adopted more and more characteristics of "private historiography." 32 We can, and indeed should, place Wang Chuzhi's tomb inscription within this tradition of private historiography. Herbert Franke once noted that "a suitable definition [of private historiography] might be that the concept of 'private' should be measured according to the degree of independence from bureaucracy, particularly from the historical offices in the capital." ${ }^{33}$ Official historiography was not only frequently mute about many classes of events, developments and individuals, but it also espoused a distinct set of moral attitudes. According to Burton Watson, "[i]t is ... highly disquieting to discover that the taishi or grand historian of Jin, rather than recording the facts as they occurred, is actually shown falsifying

31) Whether Wang Du killed his father or forced him to retire (by words or by physical violence) is in the end a matter of degree, since neither action would have been considered pious behavior in the strict Confucian moral sense.

32) Elsewhere I have shown that this trend toward private historiography was particularly pronounced during the Song dynasty. See Angela Schottenhammer, Grabinschriften in der Song-Dynastie (Heidelberg: edition forum, 1995); Schottenhammer, "Characteristics of Song Epitaphs.”

33) Herbert Franke, "Some Aspects of Chinese Private Historiography in the Thirteenth and Fourteenth Centuries." In Historians of China and Japan, eds W. G. Beasley and E. G. Pulleyblank (London: Oxford University Press, 1961): 115. 
the record in order to make a moral point concerning the ultimate responsibilities of government." "'To make a moral point," that is, to punish the bad and encourage the good (cheng e quan shan 懲惡勸善), is a leading maxim of Chinese historiography. Praise and blame (baobian 依貶), and good and bad, supersede true and false as historiographical criteria. Alternative accounts and personal opinions are not absent from official historiography, but they are, as a rule, set apart from the main text, as a commentary at the end of a chapter or as an annotation inserted in small print into the main text, often marked by the phrase "X says" ( $\mathrm{X}$ yue 曰: chenguang yue 臣光曰, junzi yue 君子曰, etc.). Such opinions are sometimes phrased as questions, but not infrequently they present a counternarrative that contradicts later official historiography.

An author composing private historiography, independent from this official historiography, need not completely reject the ideological concepts and Confucian morality of his time. But the crucial point is that, being discontent with the practical results of a strict application of this established morality, such an author could argue for exceptions to the general rules of morality —odd or difficult circumstances that required extraordinary measures that conventional standards might condemn. The morality of official historiography could therefore disparage persons whom an author of private historiography might consider right or good, and could decry actions that he might perceive to contribute to a higher moral purpose. Authors of funerary inscriptions were also at liberty to record what they considered important and what they considered to be true, pre-empting thereby the concealment or manipulation that might distort crucial deeds or events in the official historical record of later years.

In this context, we should also consider the "socio-religious" quality of tomb inscriptions. ${ }^{35}$ In the tenth century, a tomb inscription was intended in the first place to be placed into the tomb and to be buried with the deceased, and hence was not primarily composed for living descendents. ${ }^{36}$

34) Burton Watson, The Tso chuan: Selections from China's Oldest Narrative History (New York: Columbia University Press, 1989): 80.

35) On this notion, see Schottenhammer, "Das Grab": 80.

36) The common argument that tomb inscriptions originated in $278 \mathrm{CE}$, when Cao Cao issued a prohibition against the erection of inscribed steles at tombs, is not plausible, although the prohibition undoubtedly encouraged the use of tomb inscriptions as a substitute for lavish burials. First, tomb inscriptions were placed inside tombs prior to the prohibition and, second, tomb inscriptions serve a different function from tomb steles, as they 
The tomb would, as a rule, remain closed, never again to be opened. ${ }^{37}$ Who, then, was the intended audience of these texts? To whom were they addressed? The only reasonable possibility is that the inscribed stone was intended for the powers-whoever the author believed these to be-that presided over the after-life. Above all, tomb inscriptions appear to have been addressed to the community of ancestors of the deceased (Seelengemeinschaft der Ahnen), both those who had preceded him in death and those who would follow the deceased in later years. ${ }^{38}$

These general characteristics of private historiography evidently apply to the tomb inscription of Wang Chuzhi. He Zhaoxun judged that the chaotic times that he, the deceased, and Wang Du experienced, merited exceptions to conventional historiographical morality. Afraid that official historiography might misinterpret, or even condemn, a person like Wang Chuzhi-not to mention his own behavior or that of Wang Du-he construed a narrative that shows how Chuzhi's career contributed to a supraordinate moral goal. The inscription insists that Wang Chuzhi was a good person, and supports this assertion by means of a complex range of striking historical allusions. The tomb inscription shows, therefore, how in the realm of private historiography an author could articulate his own opinion, along with cautious criticism. ${ }^{39}$ In other words, the notion of the "private" in this essay connotes not only independence from official censorship, but especially the expression of personal views and opinions of the author, including critical opinions about persons, topics, and events.

A comparison of the narrative of Wang Chuzhi's life and death as recorded in the tomb inscription, to representations of his deeds in official

constitute part of the death rituals and are not simply commemorative steles buried underground. See footnote 5 for additional references.

37) Later during the Song dynasty, Zhu Xi 朱喜 (1130-1200) expounded in his Family Rituals (Jiali 家禮) that tomb inscriptions should never be accessible to the public. Zhu even recommended that the inscription and its cover be clamped together by iron straps in order to conceal the text of the inscription from any observers. Cf. Patricia B. Ebrey, Chu Hsi's Family Rituals: A Twelfth-Century Chinese Manual for the Performance of Cappings, Weddings, Funerals, and Ancestral Rites (Princeton: Princeton University Press, 1991): 108-9, 201.

38) For a detailed development of this argument, see Schottenhammer, "Einige Überlegungen zur Entstehung von Grabinschriften": 21-59.

39) Although the narrative of at least some Five Dynasties tomb inscriptions may be categorized as a form of private historiography, it remains to be investigated how common was the kind of historiographical criticism expressed in Wang Chuzhi's tomb inscription. See below for further discussion. 
histories permits us to draw cautious conclusions about the motivations and intentions of the author of the tomb inscription and about the motivations and intentions of later historians. Of particular interest in this context are two aspects of Wang Chuzhi's life: his plan to forge a strategic alliance with the Khitan Liao 契丹遼, ${ }^{40}$ and the circumstances of his death. Especially the shifting treatment of the diplomatic stratagems of the Five Dynasties offers an excellent example of the predominance of current moral attitudes in official histories.

\section{Wang Chuzhi's Biography in Other Sources}

Wang Chuzhi has an official biography in the Old History of the Tang by Liu Xu 劉煦 (887-964), the Old History of the Five Dynasties by Xue Juzheng 薛居正 (912-981), and the New History of the Five Dynasties by Ouyang Xiu 歐陽修 (1007-1072). ${ }^{41}$ In addition, the political circumstances around his person are described in Sima Guang's 司馬光 (1019-1086)

40) The tomb stele (shendao beiming 神道碑銘) of Fan Zhongyan 范仲淹 (989-1052), composed by Ouyang Xiu, offers another example of a stone inscription that diverges from official historical accounts, as it provides a detailed account of the diplomatic engagements between the Song Empire and the Xi Xia Empire of the Tanguts, around the time of its foundation by Zhao Yuanhao 趙元吴 in 1038. According to the stele, Zhao Yuanhao repeatedly proposed peace negotiations, but his attempts to avoid war are much less evident in the official historiography, probably because of the subsequent defeats suffered by the Song Empire. See Ouyang Xiu 歐陽修, Ouyang Wenzhong quanji 歐陽文忠全集 (Sibu congkan edition): 20.9a-15b; Fan Zhongyan, Fan Wenzhenggongji 范文正公集 (Sibu congkan edition): vol. 9: Baoxian ji 裹賢集: 1b-5b.

41) See Liu Xu, Jiu Tang shu: 182.4701; Xue Juzheng, Jiu Wudai shi: 54.731; Ouyang Xiu and Song Qi 宋祁, Xin Wudai shi 新五代史 (1060; reprint Beijing: Zhonghua shuju, 1974): 39.419-422. The two-page biography of Wang Du in the Old History of the Five Dynasties is considerably longer than the brief entry on Wang Chuzhi, which has been copied from the Jiu Tang shu. See Xue Juzheng, Jiu Wudai shi: 54.731-3. On the compilation of the Jiu Wudai shi, see Wang Gungwu, "The Chiu Wu-tai shih and History Writing During the Five Dynasties." Asia Major 6 (1957): 1-22. As he notes on page 9, "[t] here is evidence that Imperial and Court Diaries and administrative reports, as well as biographical notices of the chief figures during this reign, were collected by the History Office till the last years of the dynasty [i.e., the Later Tang, A.S.]. But the Hou-T'ang successors were determined to regard the Liang as a 'false' dynasty and no attempt was made to preserve them." When Li Qi 李琪, a former Chief Minister of the Liang, composed a tomb stele (shendao beiming) for Huo Yanwei 霍彦威, a former general of the Liang, he was summarily ordered to rewrite his inscription because he had neglected to refer to the Liang as a "false" (wei 偽) dynasty. See Xue Juzheng, Jiu Wudai shi: 40.553. In such cases, buried 
Comprehensive Mirror for Aid in Government (Zizhi tongjian 資治通鑑) and in Zhu Xi's 朱喜 (1130-1200) Outline and Detail of the Comprehensive Mirror for Aid in Government (Zizhi tongjian gangmu 資治通鑑綱目). ${ }^{42} \mathrm{Ma}$ Duanlin's 馬端臨 (1254-1325) Comprehensive Examination of Important Documents (Wenxian tongkao 文獻通考) mentions Wang Chuzhi in its account of the political environment of the Five Dynasties, which concentrates, however, on battles against the Khitan Liao. ${ }^{43}$

When assessing the depiction of a person in an official biography (liezhuan 列傳), we should always be aware that the individual was described as part of a larger political history and that his or her performance served primarily to exemplify the overall character of the era as the historian viewed it. ${ }^{44}$ "It was an immemorial principle that all history should provide men with a 'mirror' of the past, in which they might discern the lessons of human experience, and find models with which to confront their own actions. The purpose of biographies, like that of the Accounts of Conduct or of memorial inscriptions, was to provide posterity with models for emulation" 45 — or to stand as a warning. The purpose and function of official historiography in imperial China, to use the words of Achim Mittag, were, first, to produce knowledge for the ruler and, second, to legitimize the ruler. ${ }^{46}$ Below, I briefly summarize Wang Chuzhi's biogra-

tomb inscriptions can preserve truths otherwise deleted from transmitted texts and public inscriptions.

42) See Sima Guang 司馬光, Zizhi tongjian 資治通鑒 (1084; reprint Shanghai: Shanghai guji chubanshe, 1995): 271.1887; Zhu Xi 朱喜, Zizhi tongjian gangmu 資治通鑑綱目 (1172; Siku quanshu edition): 55.12a-13b.

43) See Ma Duanlin 馬端臨, Wenxian tongkao 文獻通考 (c. 1308; reprint Taipei: Shangwu yinshuguan, 1987): 345.2702 .

44) As Denis Twitchett puts it, "The lieh-chuan were part of the larger plan of the history, designed to flesh out with illustrative examples the bare bones of the chronicle provided by the Basic Annals and to give the reader details about a representative sample of people who not only played important roles in the events but would, taken together, exemplify and illuminate the overall character of the era as the historian conceived it." See Denis Twitchett, The Writing of Official History under the T'ang (Cambridge: Cambridge University Press, 2002): 62-3.

45) Twitchett, The Writing of Official History: 78.

40) "Auf die Frage, welche Funktion die offizielle Geschichtsschreibung im alten China hatte, kann man eine knappe Antwort geben: zum einen Herrscherwissen erzeugen und zum anderen Herrschaftslegitimation schaffen. Dafür stehen paradigmatisch das verschiedentlich schon erwähnte Zizhi tongjian.... des Sima Guang, sowie die im Shangshu grundgelegte und in den Dynastiengeschichten perpetuierte Lehre vom Himmlischen Mandat 
phies before analyzing in detail the historiographical judgement of Chuzhi in these sources.

In the Old History of the Tang, Wang Chuzhi's biography is appended to that of his elder half-brother, Wang Chucun. It states that Chuzhi, as military commander of Dingzhou 定州, fought fiercely against the bandits of Bian 泣 (i.e., the Liang-dynasty troops under Zhu Wen), but that he was not successful. After Zhu Wen's troops, under the leadership of General Zhang Cunjing 張存敬, once again attacked Dingzhou, Chuzhi is said to have mounted the city walls and to have declared:

"Our district has never lacked in loyalty toward the court. We have never abandoned the proper principles [shili 失禮] of behavior in the face of our neighbors beyond the boundaries. We had never thought that you would transgress upon our territory. Why do you do this?" Zhu Wen thereupon sent an emissary who answered, "Since you are dependent on Taiyuan [i.e., Zhu Wen's area of influence], why do you nevertheless weaken your neighboring province?" To this, Chuzhi replied, "My elder brother has established great merit for the royal family along with Taiyuan. Furthermore, our territories closely neighbor one another. To foster friendly relations and to maintain regular intercourse is under such circumstances the Common Way [changdao 常道]. I request that you change your plans starting from this notion." ${ }^{37}$

Although Zhu Wen agreed and withdrew, Chuzhi laid the blame for the defeat on the administrative clerk (kongmu li 孔目吏) Liang Wen 梁問. Thereupon Chuzhi feasted the victorious soldiers with 240,000 bolts of juan silk, oxen, and wine. Zhu Wen's general, Zhang Cunjing, eventually formed an alliance with Chuzhi and retreated. The Old History of the Tang then mentions some of the most important titles conferred upon Chuzhi by Zhu Wen, ending his brief biography with the words, "After a few years, he returned to the service of Zhuangzong [r. 923-925, of the Later Tang dynasty.${ }^{48}$ Some dozen years later, he was displaced [ $f e i$ 廢] from office by

(tianming 天命)." Achim Mittag, "Was heißt und zu welchem Ende betrieb man historische Kritik in China." Oriens Extremus 1-2 (2002): 29.

47) Liu Xu, Jiu Tang shu: 182.4701.

48) Emperor Zhuangzong 莊宗 (r. 923-925) was born as Li Cunxu 李存勗 and was King of Jin 晋王 before becoming emperor of the Later Tang dynasty (923-936). He was an opponent of Zhu Wen. After Zhu Wen's death, Wang Chuzhi once again allied himself with Li Cunxu. For the background of Li Cunxu, see Wang Gungwu, Divided China: 117-47. 
his son, $\mathrm{Du}$, and returned to his private residence. He subsequently died [xunzu 尋卒] at the age of sixty-one." ${ }^{49}$

The eye-catching point in Chuzhi's biography in the Old History of the Tang is that Chuzhi's battle with Zhu Wen, rendered in such lively detail in his tomb inscription, is not described at all. Instead, we read a conversation between the two sides and are told that, although Zhu Wen agreed to form an alliance with Chuzhi after the latter had lost a battle, Chuzhi blamed the defeat on one of his clerks - not even somebody specialized in military affairs. ${ }^{50}$ What is the moral lesson to be learned from this entry? It would seem that in this biography, Wang Chuzhi's unreasonable behavior toward his inferiors foretells his own demise. As a Military Commissioner, loyal to the court, he faces military difficulties. Yet even as these matters are being resolved, he still exhibits irresponsible, mean behavior toward his subordinates. This shows that he disregarded the proper relationship between lord and minister, and that therefore he was not a good governor. At the same time, his relationship with his son (whether adopted or not) was disrupted. Chuzhi had, in sum, violated the natural order both in his government and in his family. His eventual fate, being displaced by his son and forced into retirement, was therefore an appropriate, dishonorable punishment. This point was purposefully picked up again and elaborated on in Ouyang Xiu's New History of the Five Dynasties. ${ }^{51}$

The Old History of the Five Dynasties lacks an independent biography of Wang Chuzhi. The present text notes, "As for the biography of Wang Chuzhi by the historian Xue [Juzheng], there exists only the entry about Wang Du having displaced [his father] from his position, but details on Chuzhi are missing. Now we check his biography in the Old History of the Tang that says..." ${ }^{2}$ The biography from the Old History of the Tang is then copied verbatim. All the other information, such as Chuzhi's interactions with Li Yingji and his relationship to Wang Du, are included in Wang Du's biography, which follows the entry on Chuzhi.

Ouyang Xiu rewrote the former History of the Five Dynasties because he considered it replete with Buddhist ideas, and insufficiently informed by

49) Liu Xu, Jiu Tang shu: 182.4701.

50) The kongmu li, or kongmu guan 孔目官, was primarily an administrative and executive official. Cf. Wang Gungwu, Divided China: 139.

51) For a full translation of Ouyang Xiu's biography of Wang Chuzhi, see Richard L. Davis, Historical Records of the Five Dynasties (New York: Columbia University Press, 2004): 332-4. Here, I will restrict myself to the most important particulars of this biography.

52) Xue Juzheng, Jiu Wudai shi: 54.731. 
Confucian moral values. As Richard L. Davis notes, Ouyang Xiu intended to create broad narratives and was not interested in preserving the precise detail of source documents. "Clustering biographies around moral themes such as political ethics reveals a distinctly philosophical thrust to the history.... On the other hand, the Historical Records is a quintessentially and conservatively Confucian work. Both narrative and commentary are manipulated to maximize moral lessons. A conservative message is further reflected in the celebration of Chinese heroes, denigration of the 'barbarian' other, and rhetoric against assertive women, bankrupt policies and eroding family values." ${ }^{33}$ This is exactly what we observe in Ouyang Xiu's version of Chuzhi's biography.

Ouyang Xiu begins the biography with basic details about Chuzhi's family. In particular, he provides more information about Chuzhi's elder brother, Chucun, whom he describes as "ranking first in rallying recruits around the righteous principle of succouring their monarch." ${ }^{4}$ The battle at Shahe 沙河 against Zhu Wen's troops is briefly mentioned, as well as the subsequent alliance with Zhu Wen. In contrast to the biography in the Old History of the Tang, in which Zhu Wen sends a messenger to Chuzhi, Ouyang Xiu has Chuzhi send a messenger to propose an intensification of his relations with Zhu Wen and with the Liang dynasty, an act that some might have considered treasonous. For more than ten years, Ouyang Xiu continues, Chuzi's soldiers assisted the Liang in its battles with the Jin armies of Li Cunxu. And here ends, in the New History of the Five Dynasties, the description of Chuzhi's military life. The text turns instead to political intrigue, telling how Chuzhi obtained his son, Du: "Wang Chuzhi, being fond of sorcery, had a perverse man [yaowang 妖妄] as a retainer, Li Yingzhi." Li Yingzhi employed all sorts of heretical techniques, to the point that Chuzhi eventually believed him to possess divine powers. This $\mathrm{Li}$ Yingzhi gave Chuzhi, who had no son at that time, a small boy to raise, by the name of Liu Yunlang 劉雲郎. As mentioned above, the sources diverge concerning Chuzhi's relationship with Du. According to Ouyang Xiu's New History of the Five Dynasties, Chuzhi loved him "very much" (shen ai $z h i$ 甚愛之)..$^{55}$ In contrast, Sima Guang's Mirror and Zhu Xi's Outline omit the adverb "very." ${ }^{56}$ Observing Li Yingzhi's increasingly strange behavior,

53) Davis, Historical Records: xlix.

54) Ouyang Xiu, Xin Wudai shi: 39.419.

55) Ouyang Xiu, Xin Wudai shi: 39.420.

56) See Sima Guang, Zizhi tongjian: 271.1887; Zhu Xi, Zizhi tongjian gangmu: 55.12a-b. 
the "commanders and aides of Chuzhi fully foresaw calamity as the inevitable outcome of such conduct, but none could admonish him." ${ }^{57}$ Consequently, "as a precaution against the unexpected," they seized Li Yingji and eventually killed him. They also begged Chuzhi to murder Du, but he refused. Instead, "he secretly compiled a list of names of all soldiers above the rank of company commander, which he kept in a separate register, and later exploited assorted incidents to execute them. Over the course of some twenty years, no one escaped retribution. Chuzhi was himself slain by Du." ${ }^{58}$ Wang Du himself, in a biography attached to Chuzhi's, is described as a "wily man of endless intrigue, whom Chuzhi named Deputy." 59

After the episode of Li Yingji and Wang Du, Ouyang Xiu tells how Chuzhi came to be allied with the Khitan Liao. Emperor Zhuangzong planned a punitive action against Zhang Wenli 張文禮, who had killed Wang Rong 王鎔 (872-921). ${ }^{60}$ Plotting with his aides, Chuzhi said, "Zhenzhou and Dingzhou are dependent on each other. Although Wenli has to be blamed for a crime, Dingzhou cannot survive alone if Zhenzhou falls." ${ }^{1}$ He then tried to convince Emperor Zhuangzong to refrain from his plans. But the emperor showed him an intercepted letter with a wax seal, sent by Wenli to the Liang court, and said: "Wenli betrayed me, the troops cannot be stopped." ${ }^{\prime 2}$ Although his own military opposed the plan, Chuzhi secretly contacted Yu 郁, a biological son from a liaison with a concubine, ordering him to invite the Khitan to cross the border, as a check on the Jin armies. Yu bribed Abaoji 阿保機, the leader of the Khitan, to invade Jin territory with all his troops. As Abaoji mobilized his country for an invasion (rukou

\footnotetext{
7) Translation according to Davis, Historical Records: 333, with slight modifications.

58) Translation according to Davis, Historical Records: 333-4.

59) Ouyang Xiu, Xin Wudai shi: 39.420.

60) See Ouyang Xiu, Xin Wudai shi: 3.28, 26.277, 39.420. According to Ouyang Xiu, Wang Rong was the adoptive father of Zhang Wenli, just as Wang Chuzhi was the adoptive father of Wang Du.

61) Ouyang Xiu, Xin Wudai shi: 39.420. See also Sima Guang, Zizhi tongjian: 271.1887. The interdependence of Dingzhou and Zhenzhou bears an interesting resemblance to the interdependence of the states of Guo 虢 and $\mathrm{Yu}$ 虞 as described in the Tradition of Zuo: "Guo is the external defence of Yu. If Guo perish, Yu is sure to follow it... The common sayings 'The carriage and its wheel-aids depend on one another,' 'When the lips perish, the teeth become cold,' illustrate the relation between Guo and Yu." See Legge, The Ch'un Ti'ew: 143,145 .
}

62) Ouyang Xiu, Xin Wudai shi: 39.420. 
入寇 $)^{63}$ and as Dingzhou soldiers prepared to resist the Khitan intervention, a minor aide named $\mathrm{He}$ Zhaoxun urged Du to intervene. Du seized Chuzhi, imprisoned him at the Western Residence and took the position of Interim Regent. ${ }^{64}$

The entire episode about the Khitan alliance is of course new. Neither the Old History of the Tang, nor the Old History of the Five Dynasties, nor the tomb inscription - that is, none of the tenth-century sources-say anything about the Khitan. Beginning with the New History of the Five Dynasties, however, Wang Chuzhi's alleged conspiracy with the Khitan plays a central role in Song-period sources. (The unsuccessful invasion of the Liao army is also described in some detail in the History of the Liao [Liao shi 遼史] and in the Comprehensive Examination of Important Documents). ${ }^{65}$ Although more remains to be said about Chuzhi's alliance with the Khitan and about his final destiny as recorded in various Song-dynasty sources, it is already evident that Ouyang Xiu's version of Chuzhi's biography places him in a much more negative light than do the Old History of the Tang or the Old History of the Five Dynasties. In Ouyang Xiu's judgement, the former histories evidently had not portrayed Chuzhi's life and conduct with sufficient, explicit detail and had therefore failed their moral purpose of creating an effective warning that would provide posterity with a model of behavior that all should shun.

Sima Guang's Comprehensive Mirror for Aid in Government does not offer a biography of Chuzhi in the strict sense, but it does discuss several episodes in which Chuzhi makes an appearance. His historiographical purpose, after all, was "to write a chronological history roughly in accordance with the form of the Zuo Tradition [Zuozhuan 佐傳], starting with the Warring States and going down to the Five Dynasties, drawing on other books beside the Official Histories and taking in all a prince ought to know - everything pertaining to the rise and fall of dynasties and the good and ill fortune of the common people, all good and bad examples that can furnish models and warnings." ${ }^{66}$ In the intermittent chronicle of Wang

63) Literally, "their rapacious (or: pirate) hordes invaded." The phrase is the standard expression for a military action by a thoroughly despised neighboring people.

64) See Ouyang Xiu, Xin Wudai shi: 39.420.

65) See Tuotuo (Toghto) 脫脫, Liao shi 遼史 (1344; reprint Beijing: Zhonghua shuju, 1974): 2.17; Ma Duanlin, Wenxian tongkao: 345.2702.

66) E. G. Pulleyblank, "Chinese Historical Criticism: Liu Chih-chi and Ssu-ma Kuang." In Historians of China and Japan, eds Beasley and Pulleyblank: 153-4. 
Chuzhi's actions, some events are followed by a brief commentary. Chuzhi is introduced in the Mirror with the following words:

\begin{abstract}
Wang Chuzhi, the Military Commissioner of Yiwu commandery and Concurrent Secretariat Director, did not yet have a son. Li Yingzhi, a perverse man, obtained in Xingyi 陘邑 a small boy named Liu Yunlang, whom he gave to Chuzhi, saying, "This boy has a noble physiognomy," and he made Chuzhi bring him up like a son. Chuzhi named the boy $\mathrm{Du}$. When he grew up, he became crafty and full of deceit. ${ }^{67}$
\end{abstract}

Sima Guang explains that Yu, Chuzhi's son by a concubine, fled to the state of Jin, where the king, Li Keyong, gave him one of his daughters in marriage. Chuzhi meanwhile installed Du as Vice Military Commissioner. Then the Mirror tells the story about Li Cunxu's plans to punish Zhang Wenli and Chuzhi's overture to the Khitan, using a slightly different vocabulary from the New History of the Five Dynasties. For example, instead of using the extremely negative term "pirate raid" (rukou 入寇), Sima Guang explains that,

Taking advantage of the circumstance that the territory of Xinzhou [where Yu served as Military Training Commissioner] bordered on Khitan territory, Chuzhi secretly sent a messenger to $\mathrm{Yu}$, ordering him to bribe the Khitan and commanding them to violate the border and to endeavour to break the siege of Zhenzhou [wu yi jie Zhenzhou zhi wei 務以解鎮州之圍].68

Sima Guang's choice of language in this episode is more neutral in tone than Ouyang Xiu's, but the course of events is the same: Sima Guang, too, recounts the plots of He Zhaoxun and Wang Du, the kidnapping of Chuzhi, and Chuzhi's eventual death (discussed in greater detail below). ${ }^{69}$

Zhu Xi's Outline and Detail of the Comprehensive Mirror for Aid in Government continues this narrative shift, begun in Ouyang Xiu's New History of the Five Dynasties and extended in Sima Guang's Mirror, and locates the interest of Wang Chuzhi's life increasingly in his relationship with Wang $\mathrm{Du}$, his attempted alliance with the Khitan, and his death, rather than in his military career. Using Sima Guang's Mirror as a basis, Zhu Xi designed his Outline as a blueprint of Confucian ethics, organized according to the Spring and Autumn Annals (Chunqiu 春秋), a prestigious work tradition-

67) Sima Guang, Zizhi tongjian: 271.1887.

68) Sima Guang, Zizhi tongjian: 271.1887.

69) See Sima Guang, Zizhi tongjian: 271.1887. 
ally ascribed to Kongzi ("Confucius"). He divided the work into the so-called gang 綱 (the large rope of a net) - a chronological record of important events, in concise form and large script-and $m u$ 目 (eyes, items) — more detailed explanations following each gang entry in smaller print, in the form of a commentary.

The gang-entry on Chuzhi is concise and simple: "The military governor of Yiwu commandery, Wang Chuzhi, was imprisoned by his adoptive son, Du” (Wang Chuzhi wei qi jiazi Du suo qiu 王處直為其假子都所囚). ${ }^{70}$ The beginning of the commentary on this entry is taken more or less verbatim from Sima Guang's Mirror, but it ends with a quote from $\mathrm{Hu}$ Yin 胡寅 (1098-1156) and is introduced by the phrase “Mr. Hu says" (Hushi yue 胡氏曰). Hu Yin was a nephew of the better known Hu Anguo 胡安國 (1074-1138), who eventually adopted Yin as his son. $\mathrm{Hu}$ Yin shared $\mathrm{Hu}$ Anguo's interest in history and wrote Narrow Observations from Readings in History (Dushi guanjian 讀史管見), ${ }^{71}$ an influential work that aimed to apply to history the principles found in the classics. Hu Yin's work exerted great influence on Zhu Xi's Outline, and both $\mathrm{Hu}$ Yin and Zhu Xi depart from Sima Guang's view that history should be viewed as a moral lesson. ${ }^{72}$ Zhu Xi's quotation of Hu Yin's judgment of Wang Chuzhi is a case in point: instead of demonstrating Wang Chuzhi's moral failure by a detailed account of his actions and his eventual punishment, Zhu Xi cites $\mathrm{Hu}$ Yin's terse explication of universal moral relations. Hu Yin blames Li Cunxu for the disruption of the cosmic order, as he punished Zhang Wenli for killing his adoptive father, Wang Rong, but rewarded Wang $\mathrm{Du}$ for doing the same, granting Wang Du the post of the father he had murdered.

The shift in narrative focus from the tenth to the twelfth century, and the intentions of the authors that informed this shift, is best explained by a closer analysis of the passages that concern Wang Chuzhi's plan to involve the Khitan in his military strategies and that refer to his death.

70) Zhu Xi, Zizhi tongjian gangmu: 55.12a.

71) See Hu Yin, Dushi guanjian 讀史管見 (1208; Wanwei biecang edition).

72) See Conrad Schirokauer, "Chu Hsi and Hu Hung." In Chu Hsi and Neo-Confucian Education, ed. Wing-tsit Chan (Honolulu: University of Hawaii Press, 1986): 481. According to Schirokauer (498n11), a 1514 edition of the Narrow Observations has marginal annotations indicating what was incorporated into Zhu Xi's Outline. 


\section{Wang Chuzhi's Fate in Sources of the Tenth through Twelfth Centuries}

Among the tenth-century sources, the Old History of the Tang provides, as we have seen, a plain, concise description of Chuzhi's military experiences. It dedicates special attention to the political circumstances attending his defeat by the armies of Zhu Wen in 900, and to the consequences of that defeat. After recording Chuzhi's subsequent alliance with Zhu Wen and the titles conferred by Zhu upon Chuzhi, the biography ends with the words:

After a few years, he returned to the service of Zhuangzong [i.e., he broke his alliance with Zhu Wen and re-established his ties with the Later Tang]. Some dozen years later, he was displaced [ $f e i$ 廢] from office by his son, Du, and retired to his private residence. He subsequently died, at the age of sixty-one. ${ }^{73}$

This passage is reproduced verbatim in the corresponding passage in the Old History of the Five Dynasties, ending with the same laconic description of Wang Chuzhi's death. ${ }^{74}$ Neither history mentions the Khitan or any deliberations about a possible alliance with them. If Chuzhi failed to be a moral exemplar, it was not for making overtures to the Khitan-a military strategy that was not nearly as rare during the Five Dynasties as Songdynasty sources might have us believe. Wang Chuzhi's tomb inscription, of course, neither mentions the Khitan alliance nor makes reference to an imprisonment of Chuzhi by his son. The absence from tenth-century sources of any mention of Chuzhi's overture to the Khitan may indicate that the alliance never took place, but it may also indicate that the act of reaching out to this northern neighbor was not considered unusual or disloyal at that time. ${ }^{75}$ In this context it is not surprising, for example, that Wang Du allied himself with the Khitan in 928, even though he is said to have objected a few years earlier to his father's plans to do the same. ${ }^{76}$ The story of Du's alliance with the Khitan, recorded in some detail in the Old History

\footnotetext{
73) Liu Xu, Jiu Tang shu: 182.4701.

74) See Xue Juzheng, Jiu Wudai shi: 54.731.

75) For examples of such alliances, see Naomi Standen, Unbounded Loyalty: Frontier Crossing in Liao China (Honolulu: University of Hawai'i Press, 2007); Irene S. Leung, "Felt Yurts Neatly Arrayed, Large Tents Huddle Close': Visualizing the Frontier in the Northern Song Dynasty (960-1127)." In Political Frontiers, Ethnic Boundaries, and Human Geographies in Chinese History, eds Nicola Di Cosmo and Don J. Wyatt (London: Routledge/ Curzon Press, 2003): 192-219.
}

76) See Xue Juzheng, Jiu Wudai shi: 39.538-9, 54.732-3. 
of the Five Dynasties, may also serve as evidence that alliances with the Khitan and mutual border-crossings were not nearly as infrequent as Songperiod sources suggest. During the tenth century, relations with the Khitan were not considered a priori condemnable.

In his New History of the Five Dynasties, Ouyang Xiu devotes some attention to the Khitan alliance, not in the biography of Chuzhi himself but in the subsequent one of Wang Du. There we read that Chuzhi's son, Yu, offered a hefty bribe to the Khitan leader Abaoji, alias Emperor Taizu 太祖 (r. 916-926) of the Liao dynasty. ${ }^{77}$ Ouyang Xiu's striking gesture in this account is to introduce "the people of Dingzhou" in unanimous protest against the decision to invite the Khitan (er Dingren jie yan Qidan buke zhao 而定人皆言契丹不可召). This device of citing a third partyespecially an unimpeachable moral touchstone such as "the people," "the poor," "the troops," etc.- -was a useful convention of long standing, which was effective in articulating the author's judgment of the moral stature of a historical personage. The opposition of the people, in other words, condemns Chuzhi as a morally reprehensible individual: everybody opposed the alliance with the Khitan, and Chuzhi still refused to listen! Thereupon, Ouyang Xiu continues, Chuzhi's adoptive son, Du, kidnapped him. This version of the story places the blame squarely on Chuzhi while excusing Du's behavior, however impious that might be according to the strict standard.

Sima Guang, likewise, stresses that Chuzhi's own soldiers advised him not to ally with the Khitan, and in this version he also does not heed their advice. Chuzhi is punished for his wrong-headedness with a first calamity, the illness of his biological son. Sima Guang goes further, however, and gives voice to Chuzhi's soldiers:

The people of the garrison uniformly opposed calling on the Khitan for assistance. Du was also worried that Yu might snatch his place [in the ancestral line]. Thereupon he secretly plotted with the scribe, He Zhaoxun, to kidnap Chuzhi. It happened that Chuzhi was at a banquet with Zhang Wenli, east of the city. When they returned in the evening, Du lay in hiding in the prefectural residence with several hundred new soldiers. With great noise they kidnapped [Chuzhi], saying, "We commanders and soldiers do not want to call on the Khitan for the sake of the city. We ask that our Lord be ordered to return to his Western Residence."78

The subsequent Khitan invasion and defeat is also described in the History of the Liao. See Tuotuo, Liao shi: 2.17.

78) Sima Guang, Zizhi tongjian: 271.1887. 
In contrast to the New History of the Five Dynasties, in which He Zhaoxun urges Wang Du to kidnap his father, Sima Guang's version has Du and $\mathrm{He}$ Zhaoxun plot together to kidnap Chuzhi, thus attributing a shared, or at least compatible, agenda to both. ${ }^{79} \mathrm{Zhu} \mathrm{Xi}$ copied this passage from Sima Guang's Mirror verbatim into the commentary of his Outline.

What do these Song historians mean to tell us with their narratives and their comments? Despite significant differences in detail, Ouyang Xiu, Sima Guang, and Zhu Xi all introduce third parties to speak out against an alliance with the Khitan: Chuzhi's own population in Ouyang Xiu's account, and the army in the versions of Sima Guang and Zhu Xi. One could, of course, argue that these Song historians added information in order to come closer to historical truth. The alliance with the Khitan is, after all, not even mentioned in the sources from the Five Dynasties period, and it is common knowledge that many basic events of the years following the Chanqing era (821-824) are missing from the Old History of the Tang. Ouyang Xiu, Sima Guang, and Zhu Xi, however, do not offer precise accounts of Wang Chuzhi's alliance with the Khitan or of the events issuing from that alliance. Rather, they are preoccupied by the general opposition against such an alliance, and by the immediate moral retribution that befalls Chuzhi. When Wang Chuzhi rejects the advice of his own military and the people, misfortune promptly befalls him. First his biological son falls ill, then he is kidnapped by his adoptive son, and finally he dies. Even supposing for a moment that we were unaware that Ouyang Xiu, Sima Guang, and Zhu Xi infused their histories with a moral purpose, the passages translated above add up to a moral lesson too obvious for us to believe that the authors were simply moved by an insistence on historical accuracy.

The lesson inculcated by Chuzhi's fate is that compromising the integrity of the Middle Kingdom and violating the Way of Heaven brings disgrace and death. Wang Chuzhi is guilty of severe moral transgressions because he planned an alliance with a "barbarian" people and lost the support of his own subjects and of his army. This lesson is made explicit by Liu Youyi 劉友益. (1248-1332) in his Moral Standards in the Outline and Details of the Comprehensive Mirror for Aid in Government (Zizhi tongjian gangmu shufa 資治通鑑綱目書法, preface 1329 and 1332), which says: "To invite the northern barbarians and thereby to lose his people-this was the crime of Chuzhi” (Zhao di yishi zhong Chuzhi zhi zui ye 召狄以失

79) See Sima Guang, Zizhi tongjian: 271.1887. 
眾處直之罪也). ${ }^{80}$ It is obvious from numerous other sources that cooperation with the Khitan was considered disgraceful by Song times. ${ }^{81}$ Mischievous and baleful behavior naturally invokes misfortune and disaster. No wonder, then, that Chuzhi eventually suffered the disgrace of being kidnapped by his own son.

Just as the sources differ in the details of the Khitan alliance, they offer conflicting accounts of Wang Chuzhi's death. According to Sima Guang, Wang Du kidnapped and imprisoned Chuzhi, and eventually killed (jinsha 盡殺) his parents and descendents in Zhongshan 中山, as well as his trusted generals. Du then usurps his father's position as Interim Regent (liuhou 留後). The King of Jin, that is Li Cunxu, eventually endorses Du's replacement of Chuzhi. After forcing Chuzhi into retirement at the Western Residence, Wang Du and his soldiers,

also imprisoned his wife and concubines in the Western Residence, and exterminated Chuzhi's descendents in Zhongshan, as well as all the generals and assistants in whom Chuzhi placed an intimate trust. After making himself Interim Regent, Du reported everything to the King of Jin. The King of Jin thereupon replaced Chuzhi with Du. ${ }^{82}$

In Ouyang Xiu's elaborate telling, the setting of the story of Wang Chuzhi and Wang Du is even more perverse. In his biography of Wang Chuzhi in the New History of the Five Dynasties, Ouyang Xiu includes striking passages which impute a profound superstition to Chuzhi. According to Ouyang, Chuzhi was fond of sorcery and employed as a retainer the perverse $\mathrm{Li}$

80) Zhu Xi, Zizhi tongjian gangmu: 55.13b.

81) In the New History of the Five Dynasties, for example, An Chongrong 安重榮 (d. 942), the Commander of Zhenwu 振武, exclaims: "To demean the Middle Kingdom in order to venerate the barbarians is already a hardship on our down-trodden people and feeds the insatiable desires of the Khitan!" When the Khitan emissaries passed through Zhenwu en route to and from the capital, Chongrong insisted on sitting with his legs crossed, rudely upbraiding them, and refusing them the ordinary courtesies. Once he even seized and murdered envoys. See Ouyang Xiu, Xin Wudai shi: 51.583-5. Some tomb inscriptions also express anti-barbarian or anti-Khitan attitudes. Unearthed in 2001, the tomb inscription of Song Tinghao 宋廷浩, son-in-law to Li Cunxu, describes how Wu Luan 吳戀 protested against a covenant between the Khitan and Shi Jingtang 石敬瑭 (892-942), King of Jin 晉, by exclaiming to the people of Zhenzhou: "I have the custom of rites and ceremonies; how could I compare myself to the northern barbarians [yirong 夷狘]!" See Zhao Zhenhua 趙振華, “Wudai Song Tinghao muzhi kao” 五代宋廷浩墓誌考. Huaxia kaogu 4 (2003): 71-6.

82) Sima Guang, Zizhi tongjian: 271.1887. 
Yingzhi-the heretical magician who brought him Wang Du as an adoptive son. The reader also learns that Chuzhi's superstition determined his fate. Although Li Yingzhi is described in the Old History of the Five Dynasties, he is depicted in less strident language, and he is treated in the biography of Wang Du rather than in the biography of Wang Chuzhi. ${ }^{83}$ By transferring Li Yingzhi to the biography of Chuzhi and by enhancing Li's perversion, Ouyang Xiu renders Li Yingzhi into an expression of Chuzhi's character. If the connection between Chuzhi's superstitious predilections and his relation with Wang Du appeared tenuous in tenth-century sources, the connection becomes inescapable in the New History of the Five Dynasties, being forged by Chuzhi's person and character. As Chuzhi wills his own demise, Wang Du's character becomes less important. The opening phrases of Ouyang Xiu's biography of Wang Du, for example, blame Chuzhi for appointing his untrustworthy adoptive son, rather than presenting Wang Du as an independent agent of perversion: "Du was a wily man of endless intrigue. Chuzhi made him Vice Military Commissioner." ${ }^{4}$

Besides the perversions of Li Yingzhi, Ouyang Xiu also transfers much of the violence from Wang Du's biography to the life of Chuzhi. Ouyang Xiu describes how Li Kuangchou 李匡儔 of Youzhou 幽州, when he passed through Zhongshan en route to the capital, sent his armored men into the city to seize and kill Li Yingzhi. They begged Chuzhi to murder $\mathrm{Du}$ as well, but Chuzhi refused. Instead, Chuzhi kept a hidden list of everyone above the rank of company commander and executed everyone on this list. In the course of some twenty years, no one escaped retribution. Chuzhi himself was eventually slain by Du (er Chuzhi zhong wei Du suo sha 而處直終為都所殺). ${ }^{85}$ Although the Old History of the Five Dynasties describes these violent events in a similar manner, it discusses them in the biography of Wang Du. The transposition of these murders to the biography of Wang Chuzhi assists Ouyang Xiu in his intention to present Chuzhi's life as a warning example to his readers. Chuzhi's behavior toward his son, as well as Wang Du's own disposition and actions, become attributes to this purpose, as they do in Sima Guang's and Zhu Xi's treatments of the story.

The themes of perversion, violence, and superstition inform the details of Wang Chuzhi's death. The Old History of the Five Dynasties proposes

\footnotetext{
83) Xue Juzheng, Jiu Wudai shi: 54.731-2.

84) Ouyang Xiu, Xin Wudai shi: 39.420.

85) Ouyang Xiu, Xin Wudai shi: 39.421-2.
} 
that Wang Chuzhi's defeat was due to misguided but rational judgments, which led him to trust the false Wang Du and lose his territory: "Chuzhi raised [Wang Du] with love, and he intended gradually to delegate matters to him. Because all of Chuzhi's other sons were still young at that time, he made Du his Deputy Military Governor. Wang Du was also Chuzhi's son by a concubine." 86 The biography says nothing about Wang Du kidnapping his father. Xue Juzheng explicates his judgement of Wang Chuzhi in the moral assessment that concludes the fascicle containing the biographies of Wang Rong, Wang Chuzhi, and Wang Du:

The historian says [shichen yue 史臣曰]: Wang Rong occupied Zhenzhou and Yizhou and declared himself king, in hopes that his rule would last many generations. Chuzhi took Yizhou and Dingzhou and became their Military Commander, and he too entertained great expectations. The one was deceived by blandishing officials and overturned [the achievements of] his ancestors; the other doted upon a bastard son and lost his country. What were the reasons for this? When wealth and prestige have lasted long; then humaneness and duty will be neglected. When the eyes are dazzled by beauty, and the ears are seduced by music — under such conditions one cannot prevent evil before it has materialized; or perceive disaster before it has sprouted. As defeat and loss follow upon one another, who can be blamed? ${ }^{87}$

According to the Old History of the Five Dynasties, Chuzhi, by doting upon his son $\mathrm{Du}$, not only sealed his own fate but also doomed his country. His delusion prevented him from perceiving the ill omens of warning. The comparison between Wang Rong and Chuzhi was taken up again later by Zhu Xi.

In his biography of Wang Chuzhi in the New History of the Five Dynasties, Ouyang Xiu elaborates on the themes of superstition and violence, and coordinates them in the inevitable pattern of Wang Chuzhi's death. Ouyang Xiu describes Chuzhi's death as follows:

Abaoji mobilized his country for an invasion, although the soldiers of Dingzhou all opposed Khitan involvement. A minor aide named He Zhaoxun urged Du to intervene. Du subsequently kidnapped Chuzhi, imprisoned him at the Western Residence, and made himself Interim Regent. The sons and grandsons of the Wang family, as well as Chuzhi's generals and commanders, he killed and slaughtered until they were nearly extinct. On the morning of New Year's Day of the following year, he visited Chuzhi at the Western Residence. Chuzhi flew up in a rage and struck Du's chest, shouting "You

86) Xue Juzheng, Jiu Wudai shi: 54.732.

87) Xue Juzheng, Jiu Wudai shi: 54.734. 
treacherous bastard! How have I ever wronged you?" Because he had no weapons to hand, Chuzhi wanted to bite off Du's nose. Du freed his sleeve and left. Then Chuzhi was killed [jian sha 見殺]. ${ }^{88}$

Immediately following upon this gruesome episode, Ouyang Xiu recounts an anecdote that places the violent events in a cosmic moral context:

Prior to this, a yellow snake had been sighted at a shelter for commemorative steles. Chuzhi, believing it to be a dragon, gathered it up to offer sacrifices to it. There were also several hundred white magpies nesting in a wheat field. Chuzhi thought that they were attracted by his personal virtue, but the people of Dingzhou all knew that they were inauspicious. They said, "A snake that inhabits mountains and marshes now dwells in a house for humans, while magpies that nest among birds now descend to live in a field. These are signs that a petty man has usurped a high position, and those above him have lost their place." Before long, Chuzhi was indeed displaced and killed. ${ }^{89}$

This latter passage serves two functions. First, the reader perceives Chuzhi's superstition and blindness. He has grown too dazzled, too deluded to notice the damage he has caused. What kind of damage has he wrought? The passage alludes not only to his own fateful death but also, and this is the second point, to his disruption of the natural order, his distortion of the harmony of Heaven, Man, and Earth. The snake, for example, is both a generic symbol of evil and a specific representation of Wang Du-the poisonous son whom Chuzhi favored in spite of all the signs warning him against it. Consequently, both Chuzhi himself and his dynasty suffer a dire fate. When things abandon their proper distinctions, when animals dwell in precincts reserved for human beings, it foretells individual disaster as well as dynastic decline. Ouyang Xiu, therefore, does not simply record events omitted from earlier accounts. Rather, he intends an educational, moral purpose which demonstrates that the fate of Chuzhi had become inevitable.

Ouyang Xiu's account of Chuzhi's life and death thus exemplifies his general historiographical principles. He places Chuzhi's career in the cosmic context of a supra-ordinate historical cycle, in which heretical practices and blind superstition infallibly cause disaster, death, and political downfall. In this respect, Ouyang Xiu's biography of Wang Chuzhi is reminiscent

88) Ouyang Xiu, Xin Wudai shi: 39.421.

89) Ouyang Xiu, Xin Wudai shi: 39.421. Cf. Davis, Historical Records: 334-5. 
of Ban Gu's 班固 (32-92) “Treatise on State Sacrifices and Worship” (Jiaosi zhi 郊祀志) in the History of the Han (Han shu 漢書), in which Ban Gu warns that the concourse of ghosts and human beings causes calamities and dynastic decline..$^{90}$

Sima Guang closely paraphrases Ouyang Xiu's description of Wang Chuzhi's final encounter with Wang Du, but he changes the ending in order to give Chuzhi the opportunity to realize the error of his ways. The postponement of Chuzhi's death allows Sima Guang to make him a substitute for the reader, realizing the lessons that Sima Guang has meant to instil by the disturbing details of the preceding events:

In spring, on the first day, renwu, of the first month, Wang Du went to visit Wang Chuzhi at the Western Residence. In a rage, Chuzhi struck Du's chest with his fists, saying, "You treacherous bastard! How have I ever wronged you?" Lacking any weapons or blades, Chuzhi wanted to chew off Du's nose, but Du freed his sleeve and managed to escape. Before long, Chuzhi died of anger and grief. ${ }^{91}$

In the brief treatment of Wang Chuzhi in his Outline and Detail of the Comprehensive Mirror for Aid in Government, Zhu Xi does not invoke the intricate mechanisms of the moral universe but instead emphasizes basic Confucian principles. As mentioned above, Zhu Xi reduces the essential information to a single sentence, followed by a commentary copied verbatim from Sima Guang's Mirror. ${ }^{92} \mathrm{Zhu}$ Xi then expresses his own moral judgment of the episode by quoting the historian $\mathrm{Hu}$ Yin:

Mr. Hu says: "Wang Du imprisoned his father and mother, and killed their sons and grandsons. How did this differ from Zhang Wenli's actions? Yet [Li] Cunxu ordered the punishment of Wenli, while permitting Du to succeed to [his father's] position. When rewards and punishments are in such a state, what support remains for the ruler of the subcelestial realm? When the Three Bonds [between ruler and minister, father and son, and husband and wife] have dissolved, the foundation of government has perished also. Even though it may be temporarily recovered, it will be lost again in the blink of an eye. Is this not unfortunate!"'3

90) Ban Gu, Han shu (92 CE; reprint Beijng: Zhonghua shuju, 1997 [1962]): 25A.1189-91. For an interesting article that discusses this issue and its historiographical relevance, see Hans van Ess, "Implizite historische Urteile in den Opfertraktaten von Ssu-ma Ch'ien und Pan Ku.” Oriens Extremus 43,1-2 (2002): 40-50.

91) Sima Guang, Zizhi tongjian: 271.1887.

92) See Zhu Xi, Zizhi tongjian gangmu: 55.12a-13a.

93) Zhu Xi, Zizhi tongjian gangmu: 55.12b. 
Instead of worrying about the concourse of ghosts and human beings, Zhu $\mathrm{Xi}$ identifies the neglect of foundational Confucian principles as the true cause, not only of Wang Chuzhi's personal demise, but also of the decline of statesmanship and the polity of the Middle Kingdom in general. Zhang Wenli's murder of his adoptive father, Wang Rong, differed in nothing from Wang Du's murder of Wang Chuzhi. Yet, Li Cunxi punished Zhang Wenli, while he rewarded Wang Du by giving him permission to assume the position of the man he had killed (Jin wang yin yi Du dai Chuzhi 晋王因以都代處直). This disjuncture between reward and punishment in two cases of simultaneous regicide and patricide indicates a disruption of the fundamental relations between father and son and between ruler and minister so severe that the principles of statesmanship are lost in the chasm. In his assignment of praise and blame (baobian 售貶), Zhu Xi differs from Sima Guang and Ouyang Xiu by identifying the new sovereign, Li Cunxu, as the ultimate culprit. It is the King of Jin who has neglected the Three Bonds and who has thereby struck at the roots of statesmanship and political legitimacy. Although Zhu Xi reduces the lesson of Wang Chuzhi's misfortune to a basic warning about the fundamental bonds of family and government, he nevertheless makes this lesson a relevant one for his entire audience: if his readers neglect these principles, they will suffer. Abandonment of these principles inevitably leads to disaster, death, and dynastic collapse. ${ }^{94}$

Ouyang Xiu, Sima Guang, and Zhu Xi all agree that Wang Chuzhi was the agent of his own misfortune. Even in describing Chuzhi's demotion, abduction, and death at the hands of his adoptive son, all three historians use the passive voice to retain Chuzhi as the grammatical subject of his own suffering: "he was displaced by his son Du" (wei qi zi Du fei 為其子都廢), ${ }^{95}$ "Wang Chuzhi was imprisoned by his adopted son Du" (Wang Chuzhi wei qi jiazi Du suo qiu 王處直為其假子都所囚), ${ }^{96}$ "eventually Chuzhi was killed by Du" (er Chuzhi zhong wei Du suo sha 處直終為都所殺), ${ }^{97}$ “then Chuzhi was killed” (Chuzhi sui jian sha 處直遂見殺). ${ }^{98}$ Only in Sima

94) According to the History of the Liao, "a white hare climbed up the military protection wall” on the day the city walls of Zhuozhou 派州 were destroyed by Liao troops. See Tuotuo, Liao shi: 2.17. White is the color of death and mourning.

95) Liu Xu, Jiu Tang shu: 182.4701; Xue Juzheng, Jiu Wudai shi: 54.731.

96) $\mathrm{Zhu} \mathrm{Xi,} \mathrm{Zizhi} \mathrm{tongjian} \mathrm{gangmu:} \mathrm{55.12a.}$

97) Ouyang Xiu, Xin wudai shi: 39.420.

98) Ouyang Xiu, Xin Wudai shi: 39.421. The passive construction is also used in the description of Wang Rong's death: "Wang Rong was murdered by Zhang Wenli" (Rong wei Zhang Wenli suo sha 鎔為張文禮所殺). See Xin Wudai shi: 19.197. 
Guang's account do Wang Du and his soldiers actively plan and execute the imprisonment. Through the example of Chuzhi all three historians warn their readers of the dire consequences of flattery, superstition, and heretical practices (Ouyang Xiu) and the neglect of basic Confucian principles (Sima Guang and Zhu Xi). Chuzhi's credulity and delusion blinded him to the proper relations of Heaven, Man, and Earth, and prevented him from perceiving the consequences of his own actions: the loss of his prefecture and its people (both his soldiers and the civilian population), and the destruction of his own family. He perverted the natural order and social hierarchies, but was too deluded to see it.

The description of Wang Chuzhi's death in his tomb inscription differs greatly from all these later accounts. According to the tomb inscription, "Chuzhi retired to his private residence, where he studied The True Classic of the Southern Flowers Country," that is, the Zhuangzi (Chuzhi gui xidi er xi nanhua 處直歸西第而習南華). ${ }^{99}$ His final months are described in a flowery style. Wang Chuzhi is depicted as sacrificing to the North Star, writing poetry, drinking wine, and quietly enjoying his old age. If his death brings sorrow, it is the inevitable sorrow of declining health: "Alas! An incurable illness will bring sighs; the allotted lifespan cannot be changed. The shadow of the engraved bow fell into the wine cup; the sound of a halting breath resounded by the couch. ${ }^{100}$ On the eighteenth day of the first month of the twentieth year [of the defunct reign period Tianyou, i.e., $923 \mathrm{CE}]$ he passed away, at the age of sixty-one." 101 Although the allusion to "the shadow of the engraved bow" suggests that Wang Chuzhi may have hastened his own death by an imaginary disease, the entire passage clearly means to convey that Wang Chuzhi died of natural causes, at the peaceful end of his allotted span.

We need not, of course, assume that this earliest account of Wang Chuzhi's death is true, or that it is more authoritative than later accounts. After all, the author of the inscription, He Zhaoxun, is placed by some sources near the center of perverted power in Dingzhou. He might therefore have convinced Wang Du to kidnap his father, and he could have implicated himself in other ways in the estranged relationship of the father and the son. It is not surprising, then, that He Zhaoxun represents Wang

\footnotetext{
99) Wudai Wang Chuzhi mu: 65.

100) "The shadow of the engraved bow" is an allusion to men who hasten their own death by an imaginary illness - by imagining that the shadow of a bow cast into the wine cup is a snake which they ingest as they down their wine, so as not to offend their host.

101) Wudai Wang Chuzhi mu: 65.
} 
$\mathrm{Du}$ as a filial son, and Chuzhi as an upright and able Military Commissioner. In front of the community of Wang Chuzhi's ancestors and the powers of the netherworld, He Zhaoxun shows Wang Du laboring over his father's funeral and tomb, and exhibits Chuzhi's virtues and successes, pursued in his loyal service to universal morality and the restoration of the unified Tang Empire. ${ }^{102}$

The comparative vantage point obtained by the preceding analysis of the accounts of Wang Chuzhi's life and death in conventional historiography will now allow a more precise discussion of the historiographical position of He Zhaoxun's tomb inscription. From the very opening words of the inscription, the author draws the reader's attention to the political and military predicaments that beset the era. He compares the lifetime of the deceased to difficult episodes of the Han period (206 BCE-220 CE), when Xiongnu invaded the realm, and he further argues that a conventional, categorical assignment of praise and blame is not suited to describe such times:

Alas! He early ascended the platform at Nanzheng 南鄭 [modern Hanzhong, Shaanxi province], to receive the battle-axe and to dedicate himself to military campaigns; fire did not illuminate the palace at Ganquan 甘泉, to guard against the autumn raids he had devised a strategic policy. He was of commoner parents born; he was the ruler's right hand. How could one praise him with a single word of the Uncrowned King; how can one judge him by the nine categories [jiuchou 九疇] of the Great Plan [Hongfan 洪範] ${ }^{103}$

He Zhaoxun here compares Chuzhi to Liu Bang 劉邦 (256-195 BCE), the commoner who in $206 \mathrm{BCE}$ became the founding emperor of the Han dynasty. Residing in the capital Nanzheng, Emperor Gaozu 高祖 (r. 206-195 BCE) implemented successful policies to prevent raids by the nomadic Xiongnu. The inscription implies, in other words, that Wang Chuzhi emulated the great founding emperor of the Han in protecting his territory from violent forays by the Khitan, or perhaps from invasions by

102) Cf. Xiao Ting, "Wang Chuzhi muzhiming de zaikaocha": 158-77. The tomb and its interior also provide evidence of the filial devotion of the person who had it built, most probably Wang Du.

103) Wudai Wang Chuzhi mu: 64. Ganquan is the name of a Han-dynasty palace, named for nearby Ganquan Mountain, in modern Chunhua county, Shaanxi province. The Uncrowned King is Kongzi, traditionally credited with the infallible assignment of praise and blame in the Spring and Autumn Annals. "The Great Plan" is a chapter in The Book of Documents. 
rival Military Commissioners. It is difficult to think of a more flattering introduction to this tomb inscription.

The cautious criticism of the hallowed judgment of praise and blame, attributed to Kongzi, and of the nine categories of good government, associated with Sage Emperor Yu, are especially interesting. ${ }^{104}$ Phrasing his criticism as a rhetorical question, the author expresses his conviction that a man engaged in a political and military career in a difficult time such as the early decades of the tenth century, cannot be summarily praised or condemned. Indeed, how may one adjudicate good and bad, merit and failure in such times of chaos? Whether this manner of historiographical criticism occurred more frequently in contemporary tomb inscriptions awaits further research. Be that as it may, the Dunhuang manuscripts certainly show that Kongzi's principles were not held sacrosanct during these times of turmoil. ${ }^{105}$ Reinhard Emmerich suggests that criticism of Kongzi may even have been fashionable during the ninth and tenth centuries. ${ }^{106}$

104) “The Great Plan," believed to have been bestowed by Heaven upon Emperor Yu, expounds on the fundamentals of good government. There is a substantial body of literature on historical criticism and the hermeneutics of the Spring and Autumn Annals. A special issue of Oriens Extremus, published in 2002, deals specifically with historical criticism (shiping 史評). See especially the comprehensive summary of the subject in Mittag, "Was heißt." It is possible that these lines allude to Wang Mang 王莽 (45 BCE-23 CE), who may have been a remote ancestor of Chuzhi, and whom official sources describe as very superstitious. Wang Mang tried to re-establish the perfect society that was believed to have been achieved by the early Zhou kings. He failed in his attempt, and in addition caused a breakdown of diplomatic relations that led to prolonged wars with the Xiongnu and other tributary states. Wang Mang's reign was ended by the rebellion of Liu Xiu 劉秀, who proclaimed himself emperor and ruled as Emperor Guangwu 光武 (r. 25-57). Liu Xiu, in other words, restored the Han dynasty and improved relations with the Xiongnu, just as Chuzhi sought to restore the Tang dynasty and establish proper relations with its rivals. In Chinese historiography, Wang Mang is represented as a stereotype of evil. Yet in his tomb inscription, $\mathrm{He}$ Zhaoxun appears to question whether Wang Mang should be so easily condemned, and perhaps the ambiguity of this passage was intended to prompt the reader to realize the difficulty of making categorical judgments of political developments and personalities as either good or bad. The possibility that He Zhaoxun is alluding to Wang Mang is suggested by the lines following the passage translated here, in which the author asserts that Wang Chuzhi's ancestors attempted to climb Houling 緱岭 Mountain (where wondrous plants are said to grow and whence one may ascend to the world of the immortals), in order to follow the Zhou.

105) Reinhard Emmerich, ed., with the collaboration of Hans van Ess, Raoul Findeisen, Martin Kern, and Clemens Treter, Chinesische Literaturgeschichte (Weimar: Metzler Verlag, 2004): 186.

106) Emmerich, Chinesische Literaturgeschichte: 186. 
The remainder of the inscription, as discussed above, consistently compares Wang Chuzhi to historical generals who overcame the disgrace of defeat. ${ }^{107}$ Why did He Zhaoxun choose to place Chuzhi in a league of men who in time avenged themselves by victory, as Chuzhi himself did not? He Zhaoxun's invocation of Mengming is particularly instructive in this regard. The story of Mengming is described in detail in The Tradition of Zuo. Whether or not He Zhaoxun believed The Tradition of Zuo to be a commentary on the Spring and Autumn Annals (a work that he evidently attributed to Kongzi, "the Uncrowned King"), ${ }^{108}$ he clearly intended a specific comparison between the fates of Mengming and Wang Chuzhi. According to The Tradition of Zuo, Duke Mu of Qin persisted in his trust in Mengming, despite his defeat by the armies of Jin. For his refusal to dismiss Mengming, Duke $\mathrm{Mu}$ received an unequivocal, marvellous reward:

In consequence of a final expedition, he [Duke $\mathrm{Mu}$ ] was acknowledged as their leader by the Western Rong, and continued to employ Mengming. From this the superior man recognizes the style of ruler that Duke Mu of Qin was;- -what entire confidence he reposed in the men whom he employed, and with what single-heartedness he stood by them. He recognizes also the qualities of Mengming, how diligent he was and able, from his anxiety to exercise his thoughts more profitably; and the loyalty finally of Zisang 子桑 [who had first recommended Mengming], well knowing men, and introducing the good to the notice of his prince. ${ }^{109}$

He Zhaoxun, in other words, deems that but for the difficulties of the time, Wang Chuzhi would have been honored, like Mengming, as a man of loyalty, dedication, and ultimate success. The comparison of Chuzhi to $\mathrm{Fu}$ Yue goes even further, suggesting that an individual who has suffered many calamities can still be recognized as a valuable, upright person. One imagines that He Zhaoxun must have approved of Sima Qian's sentiment in this regard:

107) For a more detailed analysis of these historical generals and personalities, see Schottenhammer, "Das Grab": 73-81; Xiao Ting, "Wang Chuzhi muzhiming de zaikaocha": 171-80.

108) For scholarship on these traditional attributions see, for example, Anne Cheng, "Ch'unch'iu 春秋, Kung yang 公羊, Ku liang 嗀梁 and Tso chuan. 左傳.” In Early Chinese Texts: A Bibliographical Guide, ed. Michael Loewe (Berkeley: University of California Press, 1993): 67-76.

109) Legge, The Ch'un Ts'ew: 236. 
[T] rouble is something that comes to almost everyone some time. The Grand Historian remarks: In ancient times Emperor Shun 虞舜 was caught in a burning granary and trapped in a well; Yi Yin 伊尹 was obliged to carry tripods and sacrificial stands; $\mathrm{Fu}$ Yue 傅說 served as a convict labourer among the cliffs of Fu;... Baili Xi 百里奚 tended cattle; Zhongni [i.e., Kongzi] was threatened at Kuang 匡, and between Chen 陳 and Cai 蔡 he grew pale from hunger. All of these are what scholars call men of benevolence and followers of the Way. If even they encountered such misfortunes, how much more so must men of only ordinary character who are trying to make their way in a discordant and degenerate age? Surely the troubles they meet with will be too numerous to recount! ${ }^{110}$

If even the Sage and the worthiest men of the ancient past suffered such calamities, should not Wang Chuzhi's failures be judged more kindly? $\mathrm{He}$ Zhaoxun may have intended to apply this standard-Sima Qian's standard of heroic endurance, rather than Kongzi's measure of absolute judgmentnot only to Wang Chuzhi, but also to Wang Du, whose imprisonment of his father might have been justified as a historical necessity in the service of the Middle Kingdom. ${ }^{111}$

110) From “The Biographies of Wandering Knights” (Youxia liezhuan 游俠列傳), in Sima Qian, Shiji: 124.3812, as translated in Burton Watson, Records of the Grand Historian: Han II, third edition (New York: Columbia University Press, 1993): 410, with slight modifications. Fu Yue is also mentioned in the Mengzi and the Zhuangzi. The Mengzi says: "Shun rose from among the channelled fields. Fu Yue was called to office from the midst of his building frames... Thus, when Heaven is about to confer a great office on any man, it first exercises his mind with suffering, and his sinews and bones with toil... By all these methods it stimulates his mind, hardens his nature, and supplies his incompetencies." Mengzi VIB.15, as translated by James Legge, The Works of Mencius (Taipei: SMC Publishing, 1994 [1861]): 446. According to the Zhuangzi, Fu Yue became a sage and took his place among the stars. See Zhuangzi jishi 莊子集釋. In Zhuzi jicheng 諸子集成 (Beijing: Zhonghua shuju, 1954): vol. 3: 6.113.

111) Cf. Schottenhammer, "Das Grab": 73-81; Xiao Ting, "Wang Chuzhi muzhiming de zaikaocha": 171-80. 


\section{Conclusion}

The tomb inscription of Wang Chuzhi, composed by He Zhaoxun, may not be more authoritative than the biographies dedicated to him in later histories. Some of the detail of the inscription may not even be true. But the slab of dark stone with its painted stone cover, placed inside Wang Chuzhi's majestic tomb in Baoding, Hebei province, offers an autonomous written space in which the achievements of the deceased might be judged by an independent standard of private historiography. He Zhaoxun asserts this moral autonomy from the outset, questioning the applicability of conventional measurements of ancient pedigree in a time of military and political upheaval. He compares Wang Chuzhi to scholarly generals of the past whose kings and emperors had maintained their trust in them and thereby afforded them with an opportunity to make good their defeat by victory-an opportunity that had been withheld from Wang Chuzhi.

Conventional, public historiography did not share He Zhaoxun's positive assessment of Wang Chuzhi's life and career. In the course of the centuries, from Xue Juzheng's Old History of the Five Dynasties to Zhu Xi's Outline and Detail of the Comprehensive Mirror for Aid in Government, Wang Chuzhi's actions become increasingly pernicious, as his death becomes increasingly gruesome. In the Old History of the Five Dynasties, Wang Chuzhi is so beguiled by power and magic that he entrusts his realm to his deceitful adopted son Wang Du. Ouyang Xiu, in his New History of the Five Dynasties, elaborates these themes into a detailed moral parable, in which the deluded and besotted Wang Chuzhi upsets the cosmic order and sees his family and trusted generals slaughtered by Wang Du before suffering a humiliating death himself. Sima Guang and Zhu Xi alter details of Ouyang Xiu's account, but they too stage Wang Chuzhi, Wang Du, and Li Cunxu as characters in a cosmic moral setting.

The vilification of Wang Chuzhi in Song-dynasty historiography coincides with a general condemnation of the moral stature of the Five Dynasties as a historical period. The implication of Wang Chuzhi's biography in this general historiographical reassessment may be perceived, not only in the grim depravity of Wang Chuzhi's camp, but in the treatment of Chuzhi's alleged attempt to seek an alliance with the Khitan. This alliance is not mentioned in any of the tenth-century sources. Although the allusion to the Xiongnu in the opening lines of Wang Chuzhi's tomb inscription may well refer to the Khitan, it is not at all evident that the tomb inscription considers the Liao a more implacable foe than the people of other 
kingdoms, or that an alliance with the Khitan would be more objectionable than an alliance with any other political or military rival. Recent publications substantiate that during the Five Dynasties there did not exist a moral taboo, let alone any political restriction, on alliances with the Khitan, or on any other form of cooperation with the Khitan that might further political or military objectives. The competing states changed their borders continuously, especially when their loyalty to another kingdom had been disappointed. ${ }^{112}$ The Khitan, in other words, were not categorically set apart from other political and military rivals during these uncertain decades. In this context, it is evident that Wang Chuzhi's defeat by Zhu Wen in 900 was of the greatest importance, for it reconfigured the political map and paved the way for Zhu Wen's future victories.

During the Song dynasty, however, alliances with the Khitan came to be viewed as an act of treason. After the founding emperors of the Song had defeated their competitors and had once more established a unified imperial government, they proved unable to recover the so-called Sixteen Prefectures that had been ceded to the Liao by the kingdom of Jin. Military campaigns to recover this territory merely resulted in humiliating defeats, and in costly indemnity treaties imposed by the superior Khitan, in 10041005 and in $1042 .{ }^{113}$ A similar treaty was concluded with the Xi Xia Empire of the semi-nomadic Tangut, in 1044. ${ }^{114}$ In the words of Wang Gungwu, the Song had become "a lesser empire." 115 In this context, the Khitan became the politically and ethnically "other." An alliance with this alien power, and even mere placation of its demands, betrayed the political integrity and the cultural superiority of the Song Empire, heir to the immemorial legacy of the Middle Kingdom. Song intellectuals disparaged the crude customs of the Khitan and incriminated all foreign influences, including Buddhism and heretical practices, that had impaired the perfect

112) See Standen, Unbounded Loyalty.

113) The 1005 Treaty of Shanyuan 澶波 obliged the Song Empire to an annual payment of 100,000 taels of silver and 200,000 bolts of silk. The treaty of 1042 increased this amount to 500,000 bolts. The Khitan preferred to call these payments "tribute" (gong 貢), to suggest the formal subordination of the Song Empire.

114) See, for example, Michael C. McGrath, "Frustrated Empires: The Song-Tangut Xia War of 1038-44." In Battlefronts Real and Imagined: War, Border, and Identity in the Chinese Middle Period, ed. Don J. Wyatt (New York: Palgrave Macmillan, 2008): 151-90.

115) Wang Gungwu, "The Rhetoric of a Lesser Empire: Early Sung Relations with Its Neighbors." In China Among Equals: The Middle Kingdom and Its Neighbors, 10th-14th Centuries, ed. Morris Rossabi (Berkeley: University of California Press, 1983): 47-65. 
civilization bequeathed by the ancient sages. The period of the Five Dynasties assumed great importance in explaining the weakness of the Song Empire. It was during the Five Dynasties that the Sixteen Prefectures had been given to the Khitan, an act that to Song historians epitomized the general moral bankruptcy of that period of war and inconstancy. As numerous entries in the New History of the Five Dynasties, the Comprehensive Mirror for Aid in Government, and Outline and Detail of the Comprehensive Mirror for Aid in Government attest, during Song the Khitan had become a barbarian archenemy, and placation of this archenemy had become the consummate act of political corruption and moral depravity.

The moral censure of Wang Chuzhi's conduct in Song-dynasty sources therefore does not come as a surprise. Although Ouyang Xiu, Sima Guang, and Zhu Xi identify slightly different causes for Chuzhi's unprincipled behavior, they all agree that his overtures to the Khitan disrupted the natural order and threatened the moral and territorial integrity of the Middle Kingdom. His betrayal of civilization by seeking an alliance during Song with the barbarians made it imperative to present Wang Chuzhi as a warning example to posterity. The urgency of this moral lesson superseded demands of historical accuracy. If the facts of his life were unfamiliar, if his motivation for seeking an alliance with the Khitan was uncertain, if the circumstances of his death were unknown, historians were at liberty to supply details that were morally true, even if they were historically unwarranted. Thus, Wang Chuzhi mistook a snake for a dragon, suffered imprisonment by his own troops, and was murdered by his adopted son.

The changing contours of Wang Chuzhi's life, and the proliferating details of his death, provide an instructive example of the impact of political developments on the moral assessment of historical individuals in official historiography during the imperial period. Wang Chuzhi's tomb inscription does not dispense with moral judgment, nor does it guarantee historical truth, but its chiselled surface offered a circumscribed, autonomous, enduring space for a private account, outside the official dictates of conventional historiography. Tomb inscriptions, in other words, may preserve alternative narratives even of the most vilified individuals of conventional historiography, and historians stand to benefit from excavating this buried past. 


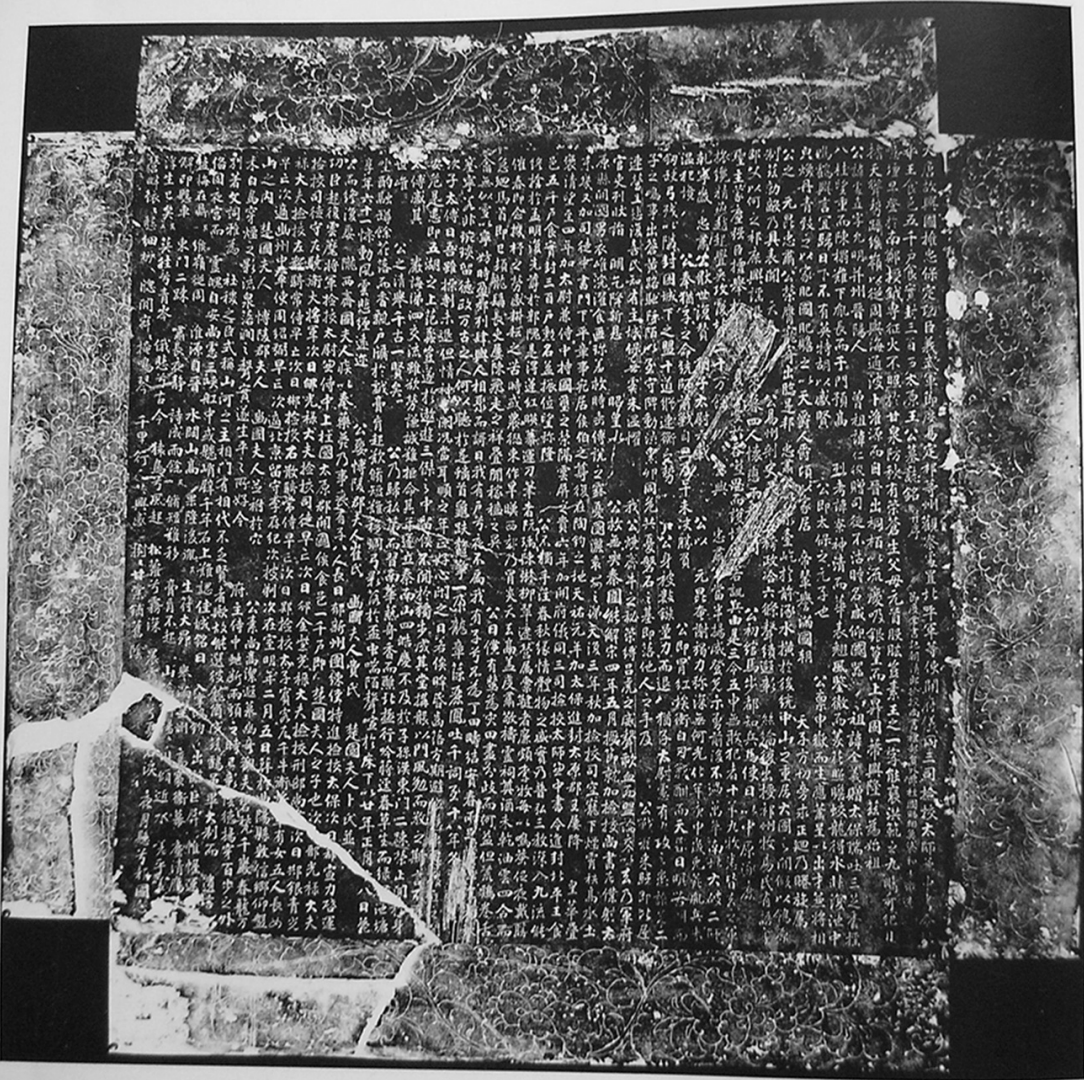

Figure 1: Original tomb inscription, unearthed from the tomb of Wang Chuzhi. Source: Hebeisheng wenwu yanjiusuo 河北省文物研究所 and Baodingshi wenwu guanlichu 保定市文物管理處, eds, Wudai Wang Chuzhi $m u$ 五代王處直墓 (Beijing: Wenwu chubanshe, 1998): plate 11 . 


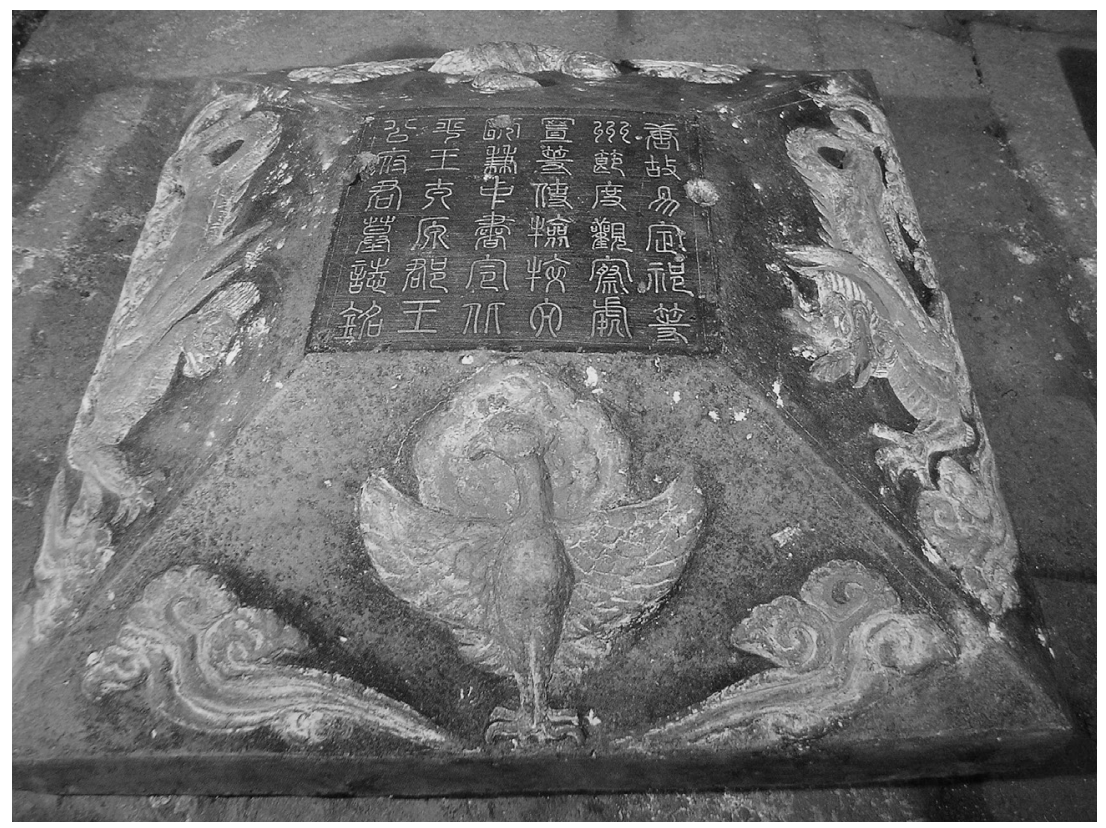

Figure 2: Cover of Wang Chuzhi's tomb inscription. Source: Hebeisheng wenwu yanjiusuo 河北省文物研究所 and Baodingshi wenwu guanlichu 保定市文物管理處, eds, Wudai Wang Chuzhi mu 五代王處直墓 (Beijing: Wenwu chubanshe, 1998): plate 16.

\section{Bibliography}

Ban Gu 班固. 1997 (92 CE; 1962). Han shu 漢書. Beijing: Zhonghua shuju.

Cheng, Anne. 1993. Ch’un-ch'iu 春秋, Kung yang 公羊, Ku liang 嗀梁 and Tso chuan 左傳. In Early Chinese Texts: A Bibliographical Guide, ed. Michael Loewe. Berkeley: University of California Press: 67-76.

Davis, Richard L. 2004. Historical Records of the Five Dynasties. New York: Columbia University Press.

Ebrey, Patricia B. 1991. Chu Hsis Family Rituals: A Twelfth-Century Chinese Manual for the Performance of Cappings, Weddings, Funerals, and Ancestral Rites. Princeton: Princeton University Press.

Emmerich, Reinhard, ed., with collaboration of Hans van Ess, Raoul Findeisen, Martin Kern, and Clemens Treter. 2004. Chinesische Literaturgeschichte. Weimar: Metzler Verlag. Fan Ye 范瞱. 1965 (fifth century). Hou Han shu 後漢書. Beijing: Zhonghua shuju.

Fan Zhongyan 范仲淹. 1053; 1089. Fan Wenzhenggong ji 范文正公集. Sibu congkan edition. 
Franke, Herbert. 1961. Some Aspects of Chinese Private Historiography in the Thirteenth and Fourteenth Centuries. In Historians of China and Japan, eds W. G. Beasley and E. G. Pulleyblank. London: Oxford University Press: 115-34.

Hebeisheng wenwu yanjiusuo 河北省文物研究所 and Baodingshi wenwu guanlichu 保定市文物管理處. 1998. Wudai Wang Chuzhi mu 五代王處直墓. Beijing: Wenwu chubanshe.

Hu Yin 胡寅. 1208. Dushi guanjian 讀史管見. Wanwei biecang edition.

Legge, James. 1994 (1861). The Works of Mencius. Taipei: SMC Publishing.

ㄴ. 1994 (1865). The Shoo King. Taipei: SMC Publishing.

- 1994 (1872). The Chinn Ts'ew with the Tso Chuen. Taipei: SMC Publishing.

Leung, Irene S. 2003. "Felt Yurts Neatly Arrayed, Large Tents Huddle Close": Visualizing the Frontier in the Northern Song Dynasty (960-1127). In Political Frontiers, Ethnic Boundaries, and Human Geographies in Chinese History, eds Nicola Di Cosmo and Don J. Wyatt. London: Routledge/Curzon Press: 192-219.

Liu Xu 劉煦. 1997 (945). Jiu Tang shu 舊唐書. Beijing: Zhonghua shuju.

Ma Duanlin 馬端臨. 1987 (c. 1308). Wenxian tongkao 文獻通考. Taipei: Shangwu yinshuguan.

McGrath, Michael C. 2008. Frustrated Empires: The Song-Tangut Xia War of 1038-44. In Battlefronts Real and Imagined: War, Border, and Identity in the Chinese Middle Period, ed. Don J. Wyatt. New York: Palgrave Macmillan: 151-190.

Mittag, Achim. 2002. Was heißt und zu welchem Ende betrieb man historische Kritik in China. Oriens Extremus 1-2: 3-39.

Ouyang Xiu 歐陽修. Ca. 1072. Ouyang Wenzhong quanji 歐陽文忠全集. Sibu congkan edition.

Ouyang Xiu 歐陽修 and Song Qi 宋祁. 1974 (1060). Xin Wudai shi 新五代史. Beijing: Zhonghua shuju.

Pulleyblank, E. G. 1961. Chinese Historical Criticism: Liu Chih-chi and Ssu-ma Kuang. In Historians of China and Japan, eds W. G. Beasley and E. G. Pulleyblank. London: Oxford University Press: 135-66.

Schirokauer, Conrad. 1986. Chu Hsi and Hu Hung. In Chu Hsi and Neo-Confucian Education, ed. Wing-tsit Chan. Honolulu: University of Hawaii Press: 480-582.

Schottenhammer, Angela. 1995. Characteristics of Song Epitaphs. In Burial in Song China, ed. Dieter Kuhn. Heidelberg: edition forum: 253-306.

- 1995. Grabinschriften in der Song-Dynastie. Heidelberg: edition forum.

2003. Das Grab des Wang Chuzhi 王處直. (863-923). In Auf den Spuren des Jenseits: Chinesische Grabkultur in den Facetten von Wirklichkeit, Geschichte und Totenkult, ed. Angela Schottenhammer. Frankfurt: Peter Lang: 61-117.

—. 2003. Einige Überlegungen zur Entstehung von Grabinschriften. In Aufden Spuren des Jenseits: Chinesische Grabkultur in den Facetten von Wirklichkeit, Geschichte und Totenkult, ed. Angela Schottenhammer. Frankfurt: Peter Lang: 21-59.

Sima Guang 司馬光. 1995 (1084). Zizhi tongjian 資治通鑒. Shanghai: Shanghai guji chubanshe.

Sima Qian 司馬遷. 1994 (91 BCE). Shiji 史記. Beijing: Zhonghua shuju.

Standen, Naomi. 2007. Unbounded Loyalty: Frontier Crossing in Liao China. Honolulu: University of Hawai'i Press. 
Twitchett, Denis. 2002. The Writing of Official History under the T'ang. Cambridge: Cambridge University Press.

Tuotuo (Toghto) 脫脫. 1974 (1344). Liao shi 遼史. Beijing: Zhonghua shuju. van Ess, Hans. 2002. Implizite historische Urteile in den Opfertraktaten von Ssu-ma Ch'ien und Pan Ku. Oriens Extremus 43,1-2: 40-50.

Wang Gungwu. 1957. The Chiu Wu-tai shih and History Writing During the Five Dynasties. Asia Major 6: 1-22.

1983. The Rhetoric of a Lesser Empire: Early Sung Relations with Its Neighbors. In China Among Equals: The Middle Kingdom and Its Neighbors, 10th-14th Centuries, ed. Morris Rossabi. Berkeley: University of California Press: 47-65.

— 2007 (1967). Divided China: Preparing for Reunification, 883-947. Singapore: World Scientific Publishing.

Watson, Burton. 1989. The Tso chuan: Selections from China's Oldest Narrative History. New York: Columbia University Press.

- 1993. Records of the Grand Historian: Han II, third edition. New York: Columbia University Press.

Xiao Ting 蕭婷 (Angela Schottenhammer). 2006. Wang Chuzhi muzhiming de zaikaocha: guanyu Wudai jiedushi jieji li de yixie daode ji yishi xingtai qushi 王處直墓誌銘的 再考察一關於五代節度使階级裡的一些道德及意識形態趨势. Zhonghua wenshi luncong 中華文史論叢 4:158-77.

Xue Juzheng 薛居正. 1997 (974). Jiu Wudai shi 舊五代史. Beijing: Zhonghua shuju.

Zhao Zhenhua 趙振華. 2003. Wudai Song Tinghao muzhi kao 五代宋廷浩墓誌考. Huaxia kaogu 4: 71-6.

Zhuangzi jishi 莊子集釋. 1954. In Zhuzi jicheng 諸子集成. Beijing: Zhonghua shuju: vol. 3: $1-481$.

Zhu Xi 朱喜. 1172. Zizhi tongjian gangmu 資治通鑑綱目. Siku quanshu edition.

Zhu Yulong 朱玉龍, ed. 1997. Wudai shiguo fangzhen nianbiao 五代十國方鎮年表. Beijing: Zhonghua shuju. 